University of Nebraska - Lincoln

DigitalCommons@University of Nebraska - Lincoln

Papers in Natural Resources

Natural Resources, School of

2012

\title{
Interannual and spatial impacts of phenological transitions, growing season length, and spring and autumn temperatures on carbon sequestration: A North America flux data synthesis
}

Chaoyang $\mathrm{Wu}$

University of Toronto, hefery@163.com

Alemu Gonsamo

University of Toronto, gonsamoa@geog.utoronto.ca

Jing Ming Chen

University of Toronto, chenj@geog.utoronto.ca

Werner A. Kurz

Canadian Forest Service-Pacific Forestry Centre, Vancouver, werner.kurz@canada.ca

Follow this and additional works at: http://digitalcommons.unl.edu/natrespapers

avid l. Price

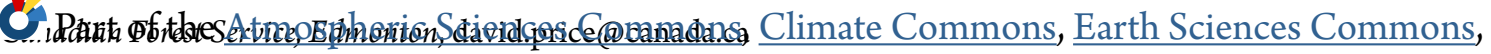
Environmental Monitoring Commons, Natural Resources and Conservation Commons, Natural See next page for additional authors
Oesour Management and Policy Commons, Other Environmental Sciences Commons, Other Oceanography and Atmospheric Sciences and Meteorology Commons, and the Sustainability Commons

Wu, Chaoyang; Gonsamo, Alemu; Chen, Jing Ming; Kurz, Werner A.; Price, David T.; Lafleur, Peter M.; Jassal, Rachhpal S.; Dragoni, Danilo; Bohrer, Gil; Gough, Christopher M.; Verma, Shashi B.; Suyker, Andrew E.; and Munger, J. William, "Interannual and spatial impacts of phenological transitions, growing season length, and spring and autumn temperatures on carbon sequestration: A North America flux data synthesis" (2012). Papers in Natural Resources. 559.

http://digitalcommons.unl.edu/natrespapers/559

This Article is brought to you for free and open access by the Natural Resources, School of at DigitalCommons@University of Nebraska - Lincoln. It has been accepted for inclusion in Papers in Natural Resources by an authorized administrator of DigitalCommons@University of Nebraska - Lincoln. 


\section{Authors}

Chaoyang Wu, Alemu Gonsamo, Jing Ming Chen, Werner A. Kurz, David T. Price, Peter M. Lafleur, Rachhpal S. Jassal, Danilo Dragoni, Gil Bohrer, Christopher M. Gough, Shashi B. Verma, Andrew E. Suyker, and J. William Munger 


\title{
Interannual and spatial impacts of phenological transitions, growing season length, and spring and autumn temperatures on carbon sequestration: A North America flux data synthesis
}

\author{
Chaoyang Wu, ${ }^{1}$ Alemu Gonsamo, ${ }^{1}$ Jing M. Chen, ${ }^{1}$ Werner A. Kurz, ${ }^{2}$, David T. Price, ${ }^{3}$ \\ Peter M. Lafleur, ${ }^{4}$ Rachhpal S. Jassal, ${ }^{5}$ Danilo Dragoni, ${ }^{6}$ Gil Bohrer, $^{7}$ Christopher M. Gough, ${ }^{8}$ \\ Shashi B. Verma, ${ }^{9}$ Andrew E. Suyker, ${ }^{9}$ and J. William Munger ${ }^{10}$ \\ 1 Department of Geography, University of Toronto, 100 St. George St., Room 5047, Toronto, ON, Canada M5S $3 G 3$ \\ 2 Natural Resources Canada, Canadian Forest Service-Pacific Forestry Centre, 506 West Burnside Road, Victoria, BC, Canada V8Z 1 M5 \\ 3 Natural Resources Canada, Canadian Forest Service, Edmonton, Alberta, Canada T6H 3S5 \\ 4 Department of Geography, Trent University, Peterborough, Ontario, Canada K9J 7B8 \\ 5 Biometeorology and Soil Physics Group, University of British Columbia, Vancouver, BC V6T 1Z4, Canada \\ 6 Department of Geography, Indiana University, Bloomington, IN 47405-7100, USA \\ 7 Department of Civil and Environmental Engineering and Geodetic Sci., Ohio State University, 417E Hitchcock Hall, 2070 Neil Ave, \\ Columbus, OH 43210, USA \\ 8 Department of Biology, Virginia Commonwealth University, Box 842012, 1000 W. Cary Street, Richmond, VA 23284-2012, USA \\ 9 Great Plains Regional Center for Global Environmental Change, School of Natural Resources, University of Nebraska-Lincoln, \\ Lincoln, NE 68583, USA \\ 10 Harvard School of Engineering and Applied Sciences, 24 Oxford St., Cambridge, MA, 02138, USA
}

Corresponding author - C. Wu, tel 647-524-0310, email hefery@163.com

\begin{abstract}
Understanding feedbacks of ecosystem carbon sequestration to climate change is an urgent step in developing future ecosystem models. Using 187 site-years of flux data observed at 24 sites covering three plant functional types (i.e. evergreen forests (EF), deciduous forests (DF) and non-forest ecosystems (NF) (e.g., crop, grassland, wetland)) in North America, we present an analysis of both interannual and spatial relationships between annual net ecosystem production (NEP) and phenological indicators, including the flux-based carbon uptake period (CUP) and its transitions, degree-day-derived growing season length (GSL), and spring and autumn temperatures. Diverse responses were acquired between annul NEP and these indicators across PFTs. Forest ecosystems showed consistent patterns and sensitivities in the responses of annual NEP to CUP and its transitions both interannually and spatially. The NF ecosystems, on the contrary, exhibited different trends between interannual and spatial relationships. The impact of CUP onset on annual NEP in NF ecosystems was interannually negative but spatially positive. Generally, the GSL was observed to be a likely good indicator of annual NEP for all PFTs both interannually and spatially, although with relatively moderate correlations in NF sites. Both spring and autumn temperatures were positively correlated with annual NEP across sites while this potential was greatly reduced temporally with only negative impacts of autumn temperature on annual NEP in DF sites. Our analysis showed that DF ecosystems have the highest efficiency in accumulating NEP from warmer spring temperature and prolonged GSL, suggesting that future climate warming will favor deciduous species over evergreen species, and supporting the earlier observation that ecosystems with the greatest net carbon uptake have the longest GSL.
\end{abstract}

Keywords: spring temperature, growing season length, carbon, gross primary production, net ecosystem production, climate change

\section{Introduction}

Terrestrial ecosystems are an important component of global carbon cycle, and recent climate change has been shown to have increasing influences on plant phenology, which in turn impacts ecosystem processes (Richardson et al., 2010 and Pan et al., 2011). Net ecosystem productivity (NEP) is a key indicator of the carbon balance of an ecosystem and represents the difference between gross primary production (GPP) and ecosystem respiration $\left(\mathrm{R}_{\mathrm{e}}\right)$. It is, thus, a measure of the net exchange of carbon dioxide between the land surface (vegetated or non-vegetated) and the atmosphere (Chen et al., 2003, Kurz et al., 2009, Zha et al., 2010 and Grant et al., 2010).

Interactions between plant phenology and climate change have been reported both at the stand (Black et al., 2000; Chen et al., 2000; Falge et al., 2002a, Liu et al., 2006, Zhang et al., 2011 and Wu et al., 2012) and the continent scales (Wang et al., 2011 and Zhu et al., 2011), indicating an urgent need to evaluate the phenological responses to climate variables to improve our understanding of terrestrial ecosystem sensitivity to future climate change (Morisette et al., 2009). A typical land surface phenology variable is the growing season length (GSL), which 
begins in the spring with increasing temperatures and light availability, the melting of snow, thawing of the soil organic horizons, and the onset of photosynthesis (Euskirchen et al., 2006). However, several definitions of GSL are used in previous research, such as number of days with air temperature $\left(\mathrm{T}_{\mathrm{a}}\right)$ above $5{ }^{\circ} \mathrm{C}$ (Chen et al., 2000 and Zhang et al., 2011), days from leaf appearance to complete leaf fall (White and Nemani, 2003), and days with net $\mathrm{CO}_{2}$ uptake from the atmosphere, which is also referred as carbon uptake period (CUP) (Churkina et al., 2005). Among these metrics, the CUP has been shown to be a better proxy than the canopy duration of the annual net ecosystem exchange (NEE; i.e., negative NEP) in deciduous forests (White and Nemani, 2003 and Baldocchi, 2008). For this reason, CUP is potentially a useful indicator of annual carbon sequestration. However, two limitations constrain the application of CUP. First, this method requires the measurement of NEE, which is made at a limited number of flux towers, further limited by the distribution and footprint of these flux towers. Although many flux networks, such as the AmeriFlux, Fluxnet-Canada, have been established, data from these networks provide critically useful but spatially limited information to be applied globally. Second, the CUP will not make sense for the recently disturbed (i.e., fire, harvest) ecosystems that have few days with positive NEP over the whole year. Therefore, alternative methods derived from remote sensing technique are proposed, such as the normalized difference vegetation index (NDVI) (Richardson et al., 2010 and Zhu et al., 2011), and the enhanced vegetation index (EVI) (Zhang et al., 2011). Recent work by Garrity et al. (2011) showed that several remote sensing indicators do not relate well to the length of the NEE season in a deciduous forest, indicating a need of in-depth analysis on these indicators across different plant functional types (PFTs).

Despite differences in the definitions of GSL, it has a significant influence on carbon uptake (White et al., 1998, Linderholm, 2006, Teklemariam et al., 2009 and Dragoni et al., 2011). For example, an increase in GSL has been shown to have a positive effect on annual NEP, e.g., around $4 \mathrm{~g} \mathrm{C} \mathrm{m}^{-2} \mathrm{~d}^{-1}$ in a subtropical forest stand (Zhang et al., 2011). Furthermore, interannual variability in GSL is also considered as one of the main factors for the spatial patterns in components of NEP, such as the $\mathrm{R}_{\mathrm{e}}$ (Valentini et al., 2000), GPP (Falge et al., 2002a), net primary production (NPP) (Fang et al., 2003), and directly on NEE (Churkina et al., 2005 and Yuan et al., 2009).

Chen et al. (2000) proposed a simple GSL method using a degree-day metric and demonstrated that GSL shows high sensitivity to the spring temperature (March to May) and increases at a rate of $5.13 \mathrm{~d} \mathrm{C}^{-1}$ for three Canadian boreal forests. These results are important as they link the spring temperature and annual carbon sequestration and provide insights into correlation between seasonal temperature variability and annual net carbon uptake. However, two main factors result in uncertainties in relating spring temperature to annual carbon sequestration. First, different PFTs show substantial variations in the relationship between NEP and GSL (Churkina et al., 2005 and Vitasse et al., 2011), which may produce errors when using similar algorithms for large-scale carbon estimation by ecosystem models. Second, the spatial sensitivity of GSL to spring temperature is unknown, which may serve as a potential reason to explain the latitudinal patterns of carbon component magnitudes because such sensitivity would have impacts on the carbon uptake (Falge et al., 2002a). Therefore, understanding of different responses and sensitivities of ecosystem carbon uptake to variability in GSL will assist in the development of improved ecosystem models to better simulate global carbon cycling under changing climatic conditions.

One unresolved issue related to phenological changes on annual carbon exchange is the differentiation between interannual variability and its spatial variations, each representing the pattern from time and space (Churkina et al., 2005 and Richardson et al., 2010). These two counterparts are equally important as interannual variability mainly controls the responses of carbon sequestration to phenological changes within sites while the spatial pattern would shed light on its spatial distribution across regions. Using data from selected sites in North America, we investigated interactions between annual NEP and a number of phenological indicators, including the flux based CUP and its transitions, degree-dayderived GSL, and spring and autumn temperatures both interannually and spatially. Such analyses were also conducted with respect to the responses and sensitivities across PFTs, including evergreen forests (EF), deciduous forests (DF) and non-forests (NF) (i.e., crops, grasslands and wetlands). The main objectives are: (1) to demonstrate the potentials of several phenological indicators in indicating annual NEP both temporally and spatially, and (2) to explore the sensitivity of these responses across different PFTs. Our hypotheses include that phenological variations play important roles in regulating temporo-spatial patterns of annual NEP and these relationships may differ among different PFTs. Such analysis would be useful in improving our knowledge of spatial heterogeneity of future climate change on carbon sequestration.

\section{Material and methods}

\subsection{Study sites}

We selected 24 North American FLUXNET sites (http://www.fluxnetcanada.ca and http://public.ornl.gov/ameriflux/dataproducts.shtml) with a total of 187 site-years of data to support our analysis and these sites cover a variety of North American sub-regions with latitudes ranging from $\sim 35^{\circ} \mathrm{N}$ to $\sim 60^{\circ} \mathrm{N}$ and longitudes from $\sim 60^{\circ} \mathrm{E}$ to $\sim 130^{\circ} \mathrm{E}$ (Fig. 1). Generally, the study sites can be classified into three PFTs, which were $10 \mathrm{EF}, 8 \mathrm{DF}$ and $6 \mathrm{NF}$ sites. The site selection was regulated by data availability, data quality (i.e., gaps during a year below $20 \%$, and were gap-filled at high level quality for each respective site during experimental years) and length of data record (e.g., at least 4 years of continuous measurements). Fig. 1 shows the dynamical ranges in mean annual temperature, precipitation and NEP for these sites, which fluctuate between 0 and $16^{\circ} \mathrm{C}$, between 400 and $1400 \mathrm{~mm}$ and between -120 and $600 \mathrm{~g} \mathrm{C} \mathrm{m}^{-2} \mathrm{y}^{-1}$, respectively. Negative NEP represents a net loss of $\mathrm{C}$ from the ecosystem to the atmosphere and positive NEP is a net gain by the ecosystem. More detailed descriptions of these sites and relevant site references are given in Table 1.

\subsection{Flux data acquisition}

Flux data provides continuous carbon exchange measurements and partitioning of NEP into its components of GPP and $R_{e}$, helps in mechanistic understanding attributed to temporal and spatial variations in NEP (Falge et al., 2002b and Law et al., 2002).

A standard procedure is used to estimate annual NEP for model evaluation. For Canadian sites, NEP is partitioned into GPP and $\mathrm{R}_{\mathrm{e}}$ using gap-filled half-hourly measurements of NEE $(=-\mathrm{NEP})$. Empirical regressions of nighttime NEE versus temperature and daytime GPP versus PAR were used to estimate $\mathrm{R}_{\mathrm{e}}$ and GPP, respectively, and gaps filled as described in Barr et al. (2004). Briefly, three steps were followed to acquire the annual NEP, GPP and $\mathrm{R}_{\mathrm{e}}$. First, the net ecosystem exchange $\left(\mathrm{F}_{\mathrm{NEE}}\right)$ is estimated as the sum of the measured eddy and air-column storage fluxes with two adjustments. The first is a correction for low turbulence, where a critical value of friction velocity $\left(\mathrm{u}^{*}\right)$ is used to filter unacceptable data. Typically values of $u^{*}>0.35 \mathrm{~m} \mathrm{~s}^{-1}$ are employed, with individual values determined for each site. The second adjustment is for poor energy-balance-closure, where turbulent fluxes (including NEP) are adjusted so that the sum of sensible and latent heat fluxes balances the net radiation minus energy storage terms. Next, measured $\mathrm{R}_{\mathrm{e}}$ is estimated as $\mathrm{R}_{\mathrm{e}}=-\mathrm{F}_{\mathrm{NEP}}$ during periods when GPP is known to be zero, i.e., at night and during both night and day in the cold season (periods 


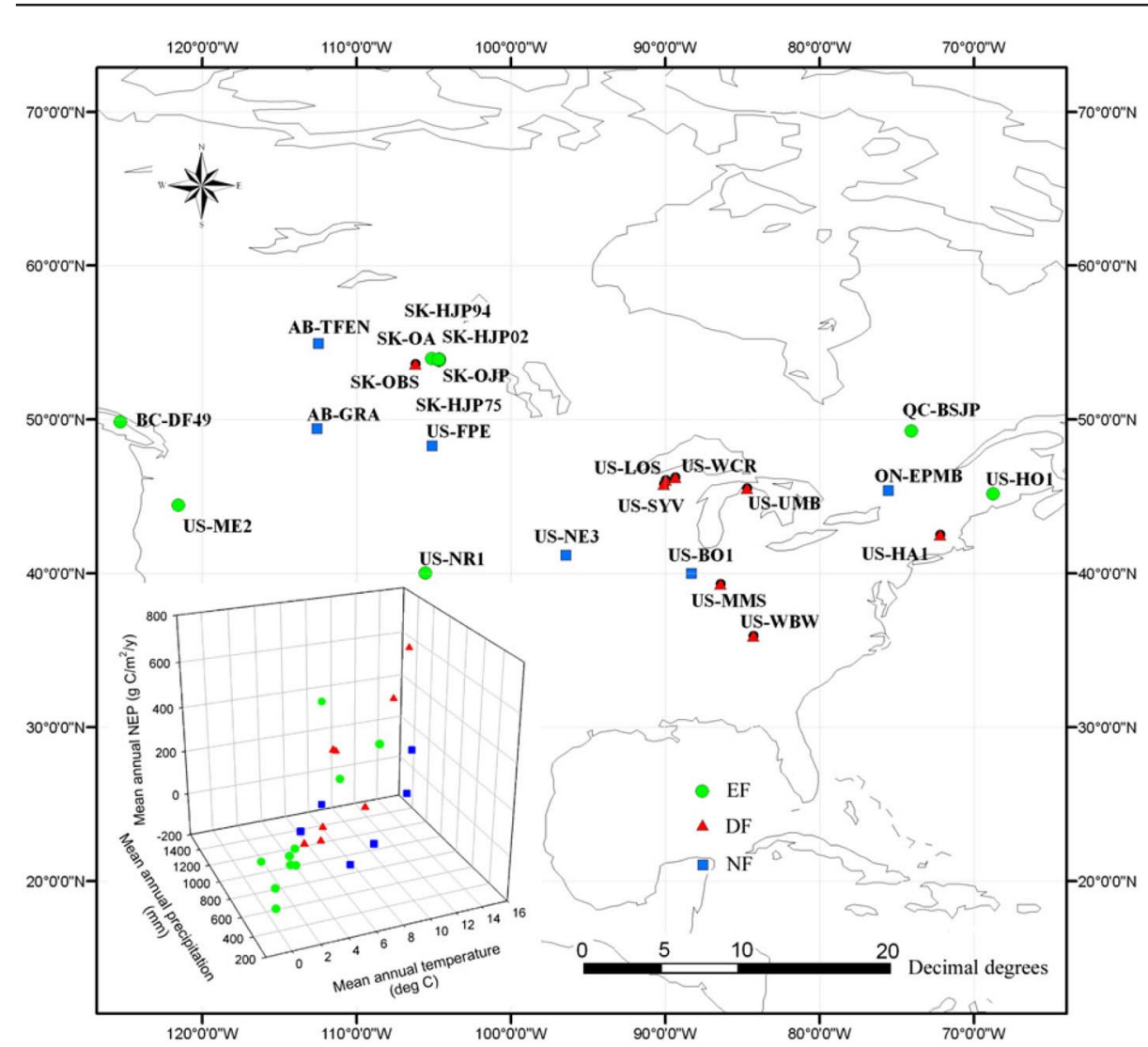

Fig. 1. Spatial distribution of study sites in this analysis. The inset indicates the distribution of mean annual temperature, precipitation and NEP for all sites. EF, DF and NF represent evergreen forests, deciduous forests, and non-forest sites, respectively.

when both air $\left(\mathrm{T}_{\mathrm{a}}\right)$ and 2-cm soil $\left(\mathrm{T}_{\mathrm{s}}\right)$ temperatures are less than $\left.0{ }^{\circ} \mathrm{C}\right)$. Finally, GPP is estimated as $\mathrm{F}_{\mathrm{NEP}}+\mathrm{R}_{\mathrm{e}}$ (daytime) or set to zero (nighttime and during periods when both $\mathrm{T}_{\mathrm{a}}$ and $\mathrm{T}_{\mathrm{s}}$ are less than $0{ }^{\circ} \mathrm{C}$ ).

For the AmeriFlux sites, level-4 monthly products were used which contain gap-filled and $\mathrm{u}^{*}$ filtered records of carbon fluxes on varying time intervals including hourly, daily, weekly, and monthly with flags regarding the quality of the original and gap-filled data. Annual GPP,
NEP, $R_{e}$ and monthly air temperature $\left(T_{a}\right)$ for each site were calculated. The half-hourly data were gap-filled using the Artificial Neural Network (ANN) method (Papale and Valentini, 2003) and/or the Marginal Distribution Sampling (MDS) method (Reichstein et al., 2005). The ANN is an empirical non-linear regression model consisting of nodes connected by weights which effectively are the regression parameters. Certain input variables, such as $\mathrm{T}_{\mathrm{a}}$, daytime vapor pressure

Table 1. Description of flux sites used in this study.

\begin{tabular}{|c|c|c|c|c|c|}
\hline Sites & & Latitude & Longitude & Year & References \\
\hline \multirow{6}{*}{ Evergreen forest (EF) } & US-NR1 & 40.0329 & -105.5460 & 1999-2007 & Monson et al. (2005) \\
\hline & US-ME2 & 44.4523 & -121.5570 & 2002-2010 & Thomas et al. (2009) \\
\hline & QC-BSJP & 49.2671 & -74.0365 & 2002-2009 & Giasson et al. (2006) \\
\hline & SK-HJP02 & 53.9447 & -104.6493 & 2003-2008 & Barr et al. (2004) \\
\hline & SK-HJP75 & 53.8758 & -104.6453 & 2004-2007 & Barr et al. (2004) \\
\hline & SK-OJP & 53.9163 & -104.6920 & 2000-2007 & Coursolle et al. (2006) \\
\hline \multirow[t]{5}{*}{ Deciduous forest (DF) } & US-HA1 & 42.5378 & -72.1715 & 1994-2006 & Urbanski et al. (2007) \\
\hline & US-LOS & 46.0827 & -89.9792 & 2001-2005 & Denning et al. (2003) \\
\hline & US-MMS & 39.3231 & -86.4131 & 2000-2008 & Dragoni et al. (2007) \\
\hline & US-SYV & 46.2420 & -89.3477 & $2002-2006$ & Desai et al. (2008) \\
\hline & US-UMB & 45.5598 & -84.7138 & 1999-2006 & Curtis et al. (2002) \\
\hline \multirow{4}{*}{ Non-forest (NF) } & US-NE3 & 41.1797 & -96.4397 & $2002-2008$ & Verma et al. (2005) \\
\hline & AB-TFEN & 54.9538 & -112.4670 & 2004-2008 & Flanagan and Syed (2011) \\
\hline & ON-EPMB & 45.4094 & -75.5187 & 2002-2009 & Admiral and Lafleur (2007) \\
\hline & AB-GRA & 49.4300 & -112.5600 & 1999-2005 & Flanagan and Adkinson (2011) \\
\hline
\end{tabular}


deficit (VPD), and radiation, are needed in the training process to produce modeled GPP and $\mathrm{R}_{\mathrm{e}}$ (Papale and Valentini, 2003, Melesse and Hanley, 2005 and Beer et al., 2010). If the required variables are not available, the MDS method using an algorithm that defines a short-term temperature sensitivity of ecosystem respiration is selected to separate NEE into GPP and $R_{e}$ (Reichstein et al., 2005). Flags with information regarding the quality of the original and gap-filled data were also added for both methods to guide the operational applications.

Desai et al. (2008) show that while partitioning methods can cause GPP or $\mathrm{R}_{\mathrm{e}}$ estimates to vary, using consistent methodology across sites allows for robust characterization of differences in GPP and $R_{e}$ across space and time. This is because flux tower NEE generally constrains GPP and $\mathrm{R}_{\mathrm{e}}$ to a range of magnitudes that do not strongly depend on partitioning techniques as discussed in more detail in Desai et al. (2008). This also agrees with the general understanding that biases associated with different gap filling methods tend to be small (Papale et al., 2006 and Moffat et al., 2007) and supports our analysis across multiple sites.

\subsection{Phenological indicators}

We calculated the CUP in the perspective of carbon flux phenology (CFP). Daily NEE over the whole year was first generated from the half-hourly measurements. The SigmaPlot (Systat Software, San Jose, CA) software was used to derive the smoothed curves of daily NEE observations for all sites. A negative exponential model using polynomial regression and weights computed from the Gaussian density function was adopted. The respective onset and end days with negative NEE can then be determined and the time duration between the two was referred to as the CUP (Fig. 2).

The GSL for each year was determined using the degree-day method as suggested previously in Chen et al. (2000). The growing season starts when the following three conditions are met, including (1) 5-day running mean $\mathrm{T}_{\mathrm{a}}>5{ }^{\circ} \mathrm{C}$, (2) no $\mathrm{T}_{\mathrm{a}}<0{ }^{\circ} \mathrm{C}$ and (3) the heat units have accumulated to at least 40 degree-days with $\mathrm{T}_{\mathrm{a}}>5^{\circ} \mathrm{C}$. The growing season ends when the following two conditions are met: (1) 5-day running mean $\mathrm{T}_{\mathrm{a}}<5{ }^{\circ} \mathrm{C}$, and (2) for any period afterward, the heat unit for $\mathrm{T}_{\mathrm{a}}>5^{\circ} \mathrm{C}$ is lower than that $\mathrm{T}_{\mathrm{a}}<5^{\circ} \mathrm{C}$.

The spring temperature referred here is the average values of $\mathrm{T}_{\mathrm{a}}$ from March 1 to May 31 (Chen et al., 2000), while the autumn temperature was computed as the mean values from September 1 to November 30 (Piao et al., 2008 and Richardson et al., 2010).

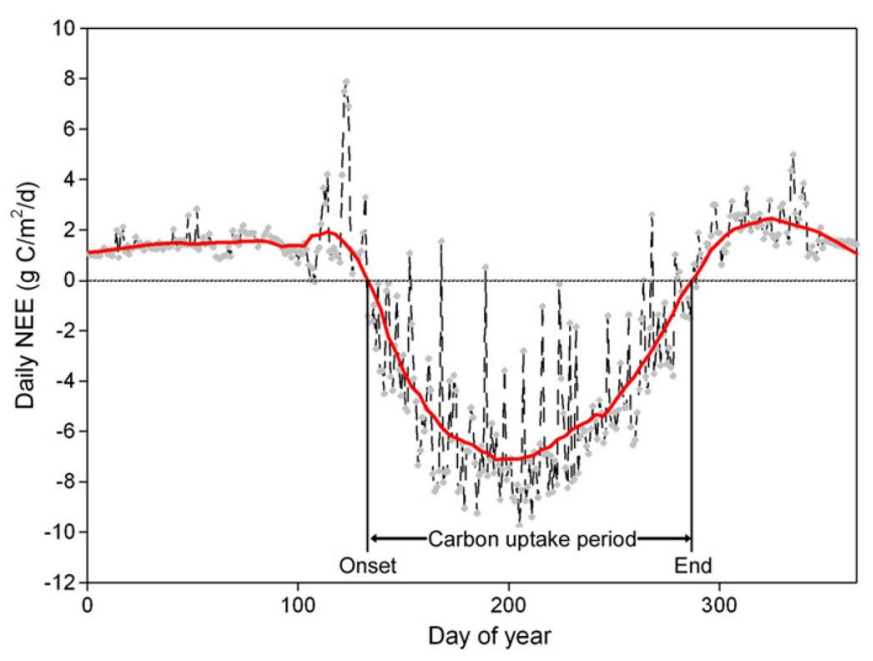

Fig. 2. An example of calculating carbon uptake period with data at USHA1 in 2001.

\subsection{Statistical analyses strategy}

Both interannual (within sites) and spatial (across sites) relationships between the phenological indicators and annual NEP were analyzed in this study and two types of statistical procedures were followed.

To analyze the interannual relationship, we first explored the correlation between the year-to-year anomalies of the phenological indicators and annual NEP, considering their diverse dynamical ranges across regions. This analysis was also classified by plant functional types, i.e., evergreen forest sites (73 site-years), deciduous forest site (56 site-years) and non-forest sites (35 site-years). Considering multiple year measurements from the same site may be not entirely independent, we used the type II regression (i.e., geometric mean regression) to investigate the interannual relationships between annual NEP and phenological indicators. When we explored the relationship between NEP and CUP, for example, we first regressed NEP on CUP and obtain a slope $\left(\mathrm{S}_{\mathrm{NEP}-\mathrm{CUP}}\right)$. Second, we regressed CUP on NEP to obtain an inverse slope $\left(\mathrm{S}_{\mathrm{CUP}-\mathrm{NEP}}\right)$. The final slope between NEP and CUP for this type II regression was calculated as:

$$
\text { Slope }=[\operatorname{sign}(r)] \sqrt{\frac{S_{N E P-C U P}}{S_{C U P-N E P}}}
$$

where $[\operatorname{sign}(r)]$ is the sign of the simple linear correlation coefficient.

With this new slope, we can then calculate the new intercept as:

$$
\text { Intercept }=N E P_{\text {mean }}-\text { Slope } \times C U P_{\text {mean }}
$$

where $N E P_{\text {mean }}$ and $C U P_{\text {mean }}$ are mean values of NEP and CUP, respectively.

To analyze the spatial pattern, the mean values as well as the standard error of these phenological indicators and annual NEP were calculated for each site ( 10 evergreen forest sites, 8 deciduous forest sites and 6 non-forest sites), both of which were then used to test the relationship spatially. Accordingly, the traditional type I regression was used. For both types of regression approaches, the coefficients of determination $\left(\mathrm{R}^{2}\right)$ and $\mathrm{p}$-value were used to evaluate these correlations.

Owing to the recent harvest, two young forests (SK-HJP02 and QCBSJP) were excluded in the analyses of carbon uptake period and its transitions on annul NEP both interannually and spatially because their daily NEE values were mostly (>99\%) positive. For analyses of growing season length and spring and autumn temperatures, these two sites were still included to explore possible indicators of annual NEP where carbon flux phenology is not unavailable or does not make sense.

\section{Results}

\subsection{Interannual variability of NEP in response to pheno- logical indicators}

\subsubsection{Impacts of CUP and its transitions on annual NEP}

The responses of interannual variations of NEP to CUP and its transitions were analyzed across different PFTs (Fig. 3). The onset of CUP was shown to be negatively correlated with annual NEP (Fig. 3a), and the $\mathrm{R}^{2}$ were $0.10(\mathrm{p}=0.032), 0.17(\mathrm{p}=0.002)$ and $0.45(\mathrm{p}<0.001)$ for EF, DF and NF sites, respectively. These observations indicate that a delayed onset of net carbon uptake would cause a reduction in the annual NEP. The delayed CUP end, on the contrary, would enhance carbon sequestration and this effect was only limited to forest ecosystems (Fig. 3b). No significant relationship was acquired in the NF ecosystems. When the CUP was explored, we observed positive impacts on annual NEP, irrespectively of PFTs (Fig. 3c).

Substantial differences were identified in the sensitivity of annual NEP to these phenological indicators interannually. Generally, the EF sites show less interannual variability in these phenological changes. 

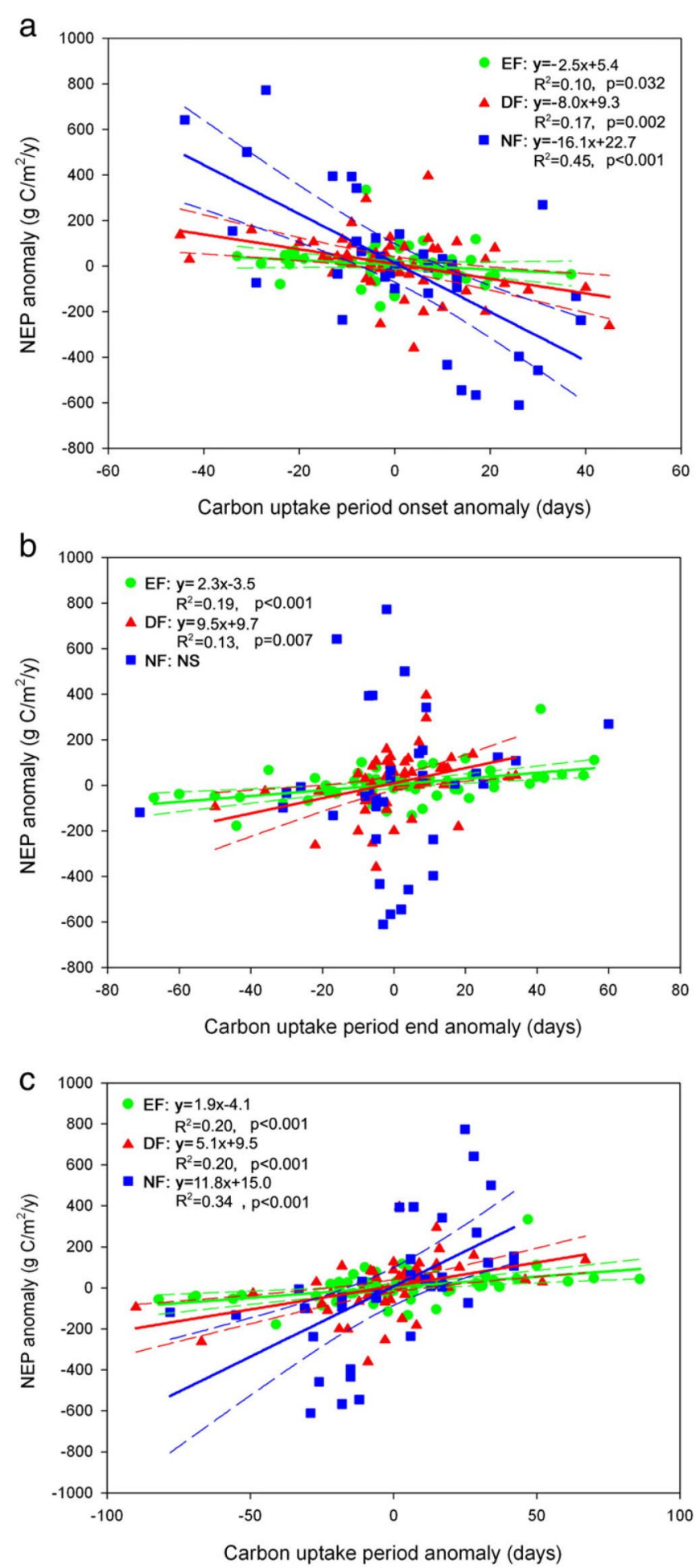

Fig. 3. Relationships between interannual net ecosystem production (NEP) anomaly and (a) the carbon uptake period onset anomaly, (b) the carbon uptake period end anomaly and (c) the carbon uptake period anomaly for the evergreen forest (EF), deciduous forest (DF), and non-forest (NF) sites. NS represents no significant correlation.

For example, one day in the delayed onset of CUP would reduce annual $\mathrm{NEP}$ by $2.5 \mathrm{~g} \mathrm{C} \mathrm{m}^{-2}$, while this rate for the DF and NF sites was $8.0 \mathrm{~g}$ $\mathrm{C} \mathrm{m}^{-2}$ and $16.1 \mathrm{~g} \mathrm{C} \mathrm{m}^{-2}$, respectively. This feature also existed when considering the responses of annual NEP to CUP and its ending transition, without referring to the relationship between annual NEP and CUP end in NF sites.

\subsubsection{Impacts of GSL on annual NEP}

Interannual variation in the GSL showed positive influences on the annual NEP with $\mathrm{R}^{2}$ of $0.17(\mathrm{p}=0.003)$ and $0.21(\mathrm{p}<0.001)$ for the EF and DF, respectively (Fig. 4). Forest sites had better correlations between annual NEP and GSL anomalies, but the NF sites showed more scatter in the distribution of NEP anomaly, leading to a lower correlation between annual NEP and GSL anomalies $\left(\mathrm{R}^{2}=0.10, \mathrm{p}=0.072\right.$, dash line). The reason was that two of these NF sites, US-BO1 and USNE3, were regulated by an annual rotation between corn (C4) and soybeans (C3), which had substantial differences in the dynamical ranges of annul NEP. Longer GSL helped to enhance annual carbon sequestration and each one additional day longer in the GSL would increase annual NEP by $3.5 \mathrm{~g} \mathrm{C} \mathrm{m}^{-2}, 6.8 \mathrm{~g} \mathrm{C} \mathrm{m}^{-2}$, and $18.4 \mathrm{~g} \mathrm{C} \mathrm{m}^{-2}$ for EF, DF and NF respectively. An analysis of variance test $(\mathrm{p}<0.05)$ showed that these slopes were significantly different, indicating variations in sensitivities to that of annual NEP to carbon flux phenology across these three PFTs.

\subsubsection{Impacts of spring and autumn temperatures on annual NEP}

The impacts of spring and autumn temperatures on interannual NEP were shown in Fig. 5. No significant relationship was observed between annual NEP and spring temperature anomalies, either for the overall dataset or for each FPTs. These results suggest that spring temperature alone may have limited potential in explaining interannual NEP variability with our dataset, although it showed to be a proxy of annual NEP for some boreal forests (Barr et al., 2007).

For autumn temperature, no significant relationship was found on annual NEP for either EF or NF sites. However, the DF sites showed an equivocal decrease (dash line) in annual NEP anomaly in warmer autumns with an $\mathrm{R}^{2}$ of 0.05 ( $\left.\mathrm{p}=0.071\right)$ (Fig. 5b). These observations imply that seasonal temperature (either spring or autumn) alone is not sufficient to provide insights of interannual NEP for ecosystems at diverse ecoregions.

\subsection{Spatial variability of NEP in response to phenological indicators}

\subsubsection{Impacts of CUP and its transitions on annual NEP}

The impacts of CUP, as well as the timing of CUP onset and end (DOY, day of year) on annual NEP were analyzed across the different PFTs. Fig. 6a shows that EF sites generally had earlier CUP onset than DF sites. A $t$-test $(\mathrm{p}<0.05)$ demonstrated that the difference is significantly different. The earliest CUP onset was observed at US-ME2 with a DOY of $14 \pm 8.2$, while all other EF sites were within 120 DOY. In contrast, DF sites showed much delayed CUP onsets and less variation within sites, ranging from DOY $103 \pm 2.8$ to $149 \pm 4.9$. The NF sites

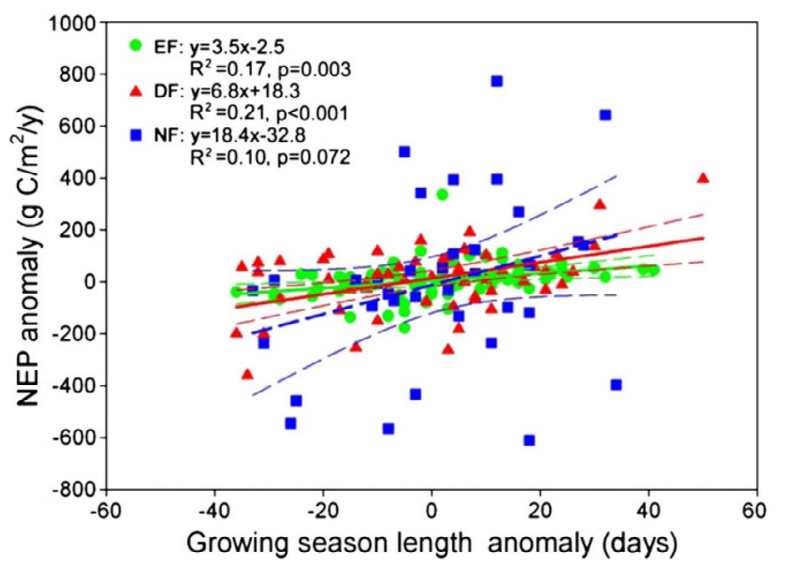

Fig. 4. Relationships between the interannual net ecosystem production (NEP) anomaly and the growing season length (GSL) anomaly for the evergreen forest (EF), deciduous forest (DF), and non-forest (NF) sites. 

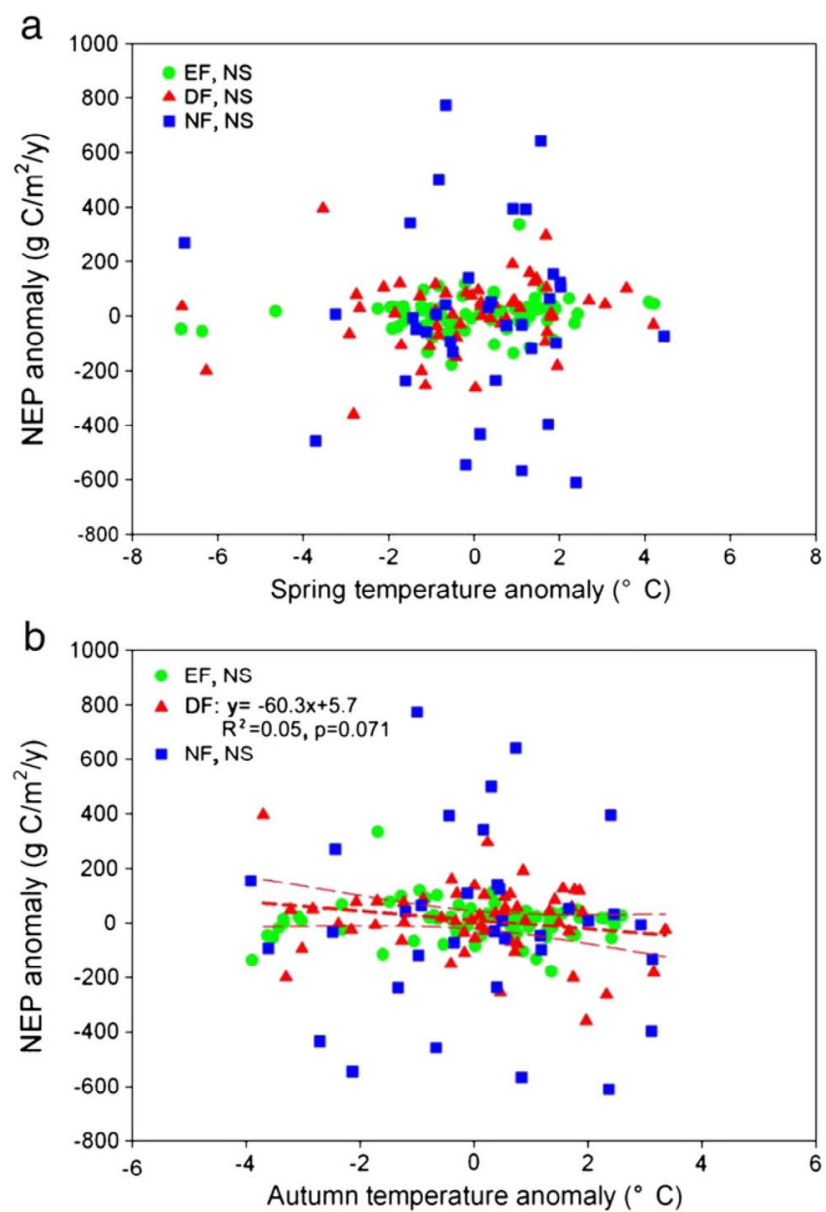

Fig. 5. Relationships between the interannual net ecosystem production (NEP) anomaly, (a) the spring temperature anomaly and (b) the autumn temperature anomaly for the evergreen forest (EF), deciduous forest (DF), and non-forest (NF) sites. NS represents no significant correlation.

had similar (no significant difference, $\mathrm{p}=0.21$ ) CUP onsets to that of DF sites with values ranging from DOY of $82 \pm 17$ to $165 \pm 6$. Relationship between CUP onset and annual NEP showed substantial variations across the different functional types. EF and DF sites both exhibited negative correlations between CUP onset and annual NEP with coefficients of determination $\left(\mathrm{R}^{2}\right)$ of $0.93(\mathrm{p}<0.001)$ and 0.88 $(\mathrm{p}<0.001)$, respectively (Fig. 6a). However, the slope of the DF regression was larger ( $t$-test, $\mathrm{p}<0.05)$, implying that annual NEP of this PFT is more sensitive to onset of CUP than that at other sites. NF sites, on the other hand, had a moderate positive relationship $\left(\mathrm{R}^{2}=0.66, \mathrm{p}\right.$ $=0.048$ ) between CUP onset and annual NEP.

EF sites show larger dynamical range in CUP end ranging from DOY of $170 \pm 5.3$ to $343 \pm 8.6$ than other two groups, while DF sites have a more concentrated CUP end for all PFTs, ranging from DOY $243 \pm 2.9$ to $319 \pm 7.2$ (Fig. 6b). The latest CUP end was observed at US-WBW with DOY of $319 \pm 7.2$, which is very similar to previous results of Wilson and Baldocchi (2000). NF sites generally had CUP end dates falling between early July and early September. Overall, the CUP end dates showed a consistent positive impact on annual NEP for these PFTs with an $R^{2}$ of $0.49(p<0.001)$ for all sites, indicating that this phenological transition can be useful in analyzing carbon sequestration. However, NEP of NF sites was not significantly correlated with the end of CUP. For forests, DF sites showed the highest sensitivity to the CUP end date (i.e., largest slope). This slope was significantly different from that of EF sites. And for each one day delay in the CUP end date, annual NEP would increase by $7.4 \mathrm{~g} \mathrm{C} \mathrm{m}^{-2} \mathrm{y}^{-1}$, which was 2.5 for EF sites.
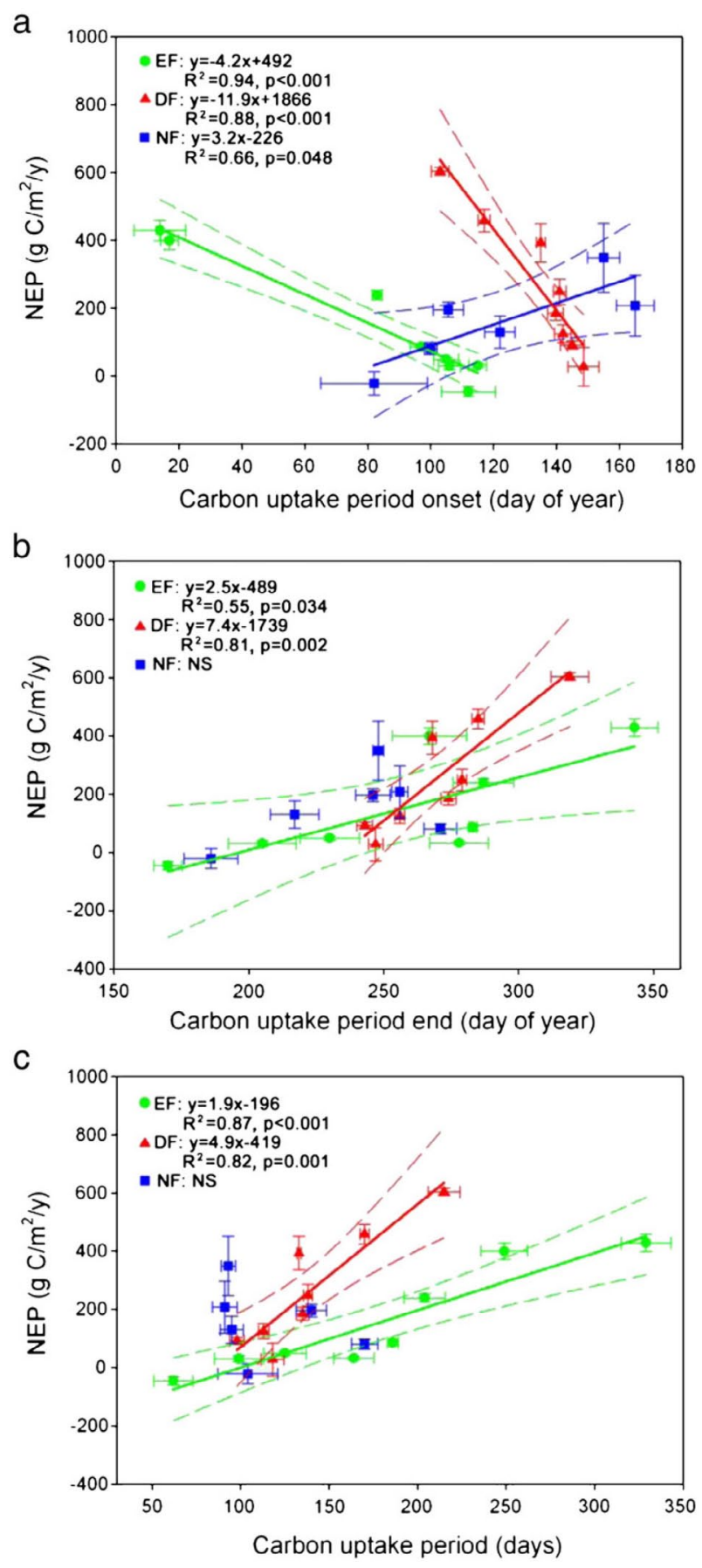

Fig. 6. Relationships between annual NEP (a) CUP onset, (b) CUP end and (c) CUP for evergreen forest (EF), deciduous forest (DF), and nonforest (NF) sites. NS represents no significant correlation. Points represent data ( \pm standard error) for each site.

The relationship between the length of CUP and annual NEP differs substantially among PFTs (Fig. 6c). While significant correlations were observed between CUP and NEP for forest ecosystems with $\mathrm{R}^{2}$ of $0.87(p<0.001)$ and $0.82(p=0.001)$ for EF and DF sites, respectively, NEP of NF sites was independent of CUP as no correlation was observed.

\subsubsection{Impacts of GSL on annual NEP}

Regressing degree-day derived GSL on annual NEP produced a significant relationship for all sites combined $\left(\mathrm{R}^{2}=0.75, \mathrm{p}<0.001\right)$ (Fig. 7). Separated into PFTs, GSL was more highly related to annual 


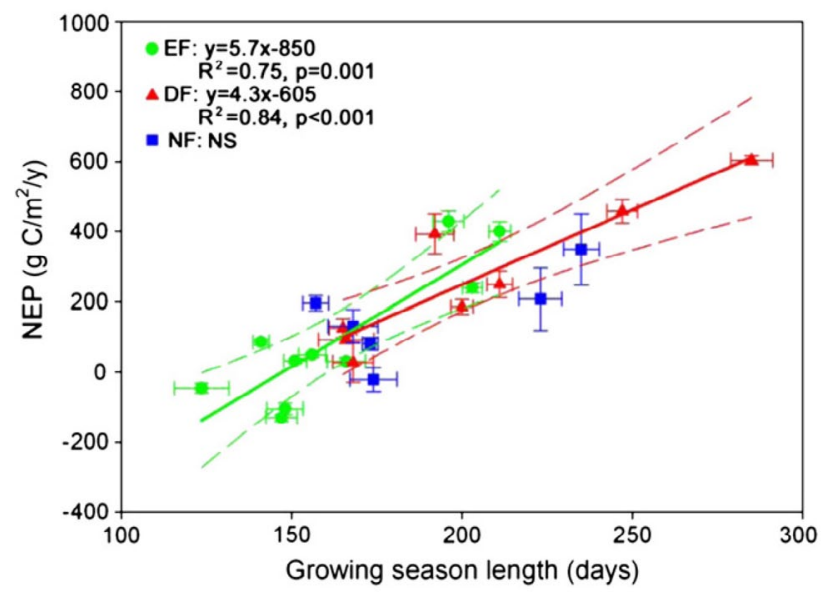

Fig. 7. Relationships between growing season length (GSL) and annual NEP for evergreen forest (EF), deciduous forest (DF), and non-forest (NF) sites. Points represent data ( \pm standard error) for each site.

NEP for forest ecosystems $\left(\mathrm{R}^{2}=0.75\right.$ and 0.84 for EF and DF, respectively) than for the NF group $\left(\mathrm{R}^{2}=0.46\right)$, which was not significant statistically $(\mathrm{p}=0.139)$ considering the limited sites in our analysis. These results suggest a reasonable possibility of incorporation of this simple GSL to explain annual carbon sequestration of forests ecosystems in future ecosystem models.

Different plant functional types tended to have their specific ranges of GSL. DF sites had the longest GSL with a mean of $204 \mathrm{~d}$. NF and EF sites had shorter GSLs with means of 188 and 164, respectively. This difference in GSL was significantly between DF and EF sites $(\mathrm{p}<0.05)$ but no significant difference was observed between NF and $\mathrm{DF}(\mathrm{p}=0.221)$ or EF $(\mathrm{p}=0.082)$ sites. The annual NEP exhibited the same pattern as GSL, mean values were 266, 157 and $98 \mathrm{~g} \mathrm{C} \mathrm{m}^{-2} \mathrm{y}^{-1}$ for $\mathrm{DF}, \mathrm{NF}$ and $\mathrm{EF}$, respectively. This pattern is consistent with existing knowledge that ecosystems with the greatest net carbon uptake have the longest growing season (Baldocchi, 2008).

The slope of the NEP-GSL regression indicates that across ecosystems in general, annual NEP would increase with GSL at a rate of $4.3 \mathrm{~g} \mathrm{C} \mathrm{m}^{-2} \mathrm{y}^{-1} \mathrm{~d}^{-1}$. However, EF sites have the larger increase $(5.7 \mathrm{~g}$ $\left.\mathrm{C} \mathrm{m}^{-2} \mathrm{y}^{-1} \mathrm{~d}^{-1}\right)$ than DF $\left(4.3 \mathrm{~g} \mathrm{C} \mathrm{m}^{-2} \mathrm{y}^{-1} \mathrm{~d}^{-1}\right)$ sites. An analysis of variance test indicates that these slopes may not be significantly different $(\mathrm{p}=0.112)$.

\subsubsection{Impacts of spring and autumn temperature on annual NEP}

Both spring and autumn temperatures were positively correlated with carbon sequestration for forest ecosystems (both EF and DF sites) (Fig. 8). However, these correlations were not observed at NF sites, indicating that neither spring nor autumn temperature can provide sufficient insight on annual NEP. For forest ecosystems, in general, spring temperature was better than autumn temperature in explaining annual NEP. The overall dataset (all sites) had slightly larger $\mathrm{R}^{2}(0.65, \mathrm{p}<0.001)$ for the spring temperature compared with the autumn $(0.63, \mathrm{p}<0.001)$.

When comparing among PFTs, EF sites had the highest correlation between annual NEP and both spring $\left(\mathrm{R}^{2}=0.90, \mathrm{p}<0.001\right)$ and autumn temperatures $\left(\mathrm{R}^{2}=0.73, \mathrm{p}=0.001\right)$. These correlations for DF were slightly lower with $R^{2}$ equal to $0.84(p<0.001)$ and $0.67(p$ $=0.011$ ) for spring and autumn temperatures, respectively. In contrast, we found poor correlations between annual NEP and spring or autumn temperatures at NF sites, indicating low potentials of either spring or autumn temperature in explaining carbon sequestration at NF sites. A possible reason for this is that carbon sequestration by NF ecosystems may be more affected by the environmental stresses over the whole growth season.
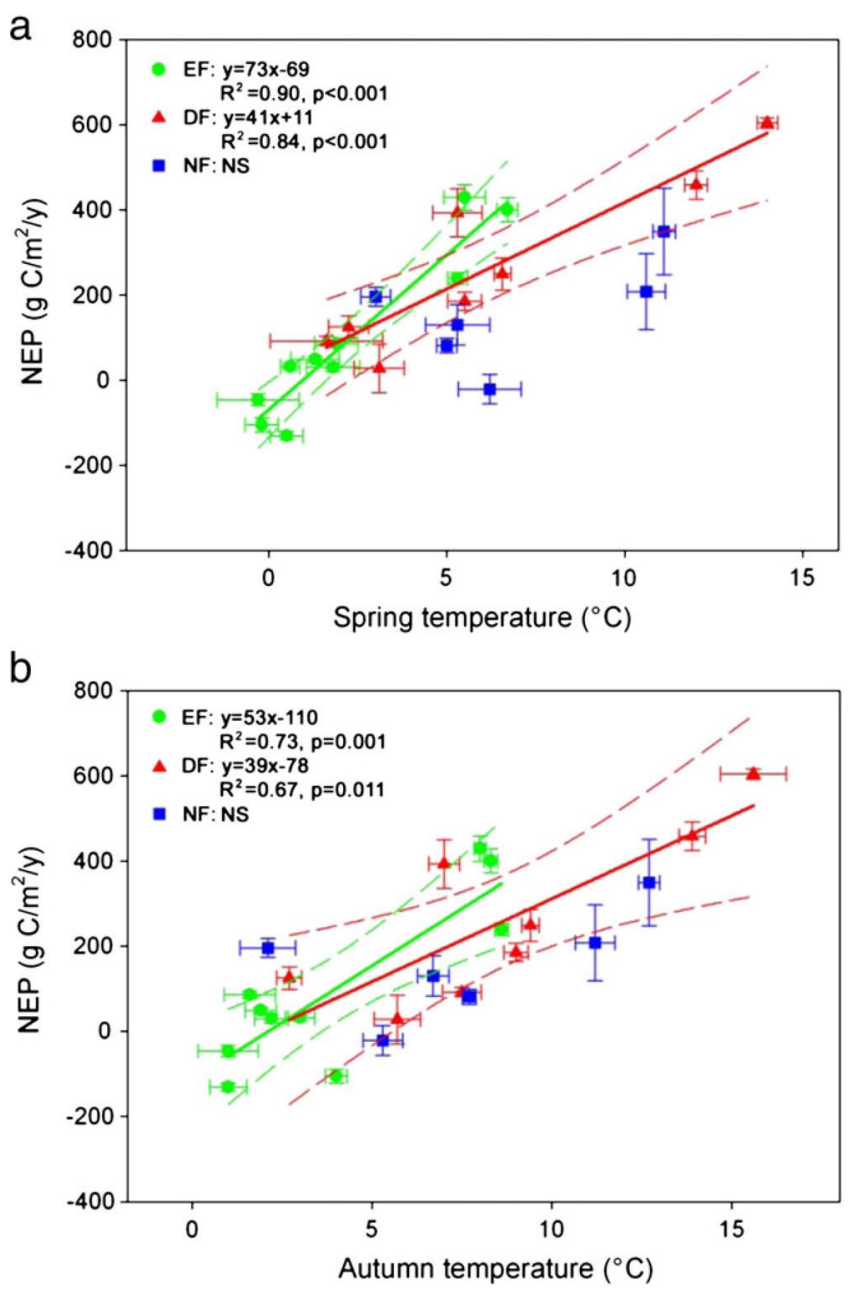

Fig. 8. Relationships between annual NEP (a) spring, (b) autumn temperature for evergreen forest (EF), deciduous forest (DF), and non-forest (NF) sites. Points represent data ( \pm standard error) for each site.

\subsection{Relationships among phenological indicators and sensitivity analysis}

\subsubsection{Relationships between GSL to CUP and its transitions}

It is important to show the correlation between the degree-day metric GSL, and the flux based phenology (i.e. CUP), which is considered as a good proxy of NEP in forests (White and Nemani, 2003). This evaluation could strengthen the reliability of GSL and provide the basis for its future applications, especially considering the empirically determined temperature threshold and its applicability to ecosystems across a range of latitudes and PFTs.

As shown in Fig. 9, GSLs for both EF and DF ecosystems were significantly correlated to CUP and its transitions, supporting the potential of using this simple degree-day metric in analyzing the impacts of phenology changes on forest carbon sequestration. The most uncertainty lies in the application in NF sites where no significant correlation was found between GSL and CUP and the end of CUP. However, as the CUP was not found to be an indicator of NEP for NF sites (Section 3.2.1), the use of GSL in NF species may still be possible (Section 3.2.2). Our results showed that while the empirical determination of GSL using a temperature threshold may be improved, it is feasible to use this procedure for sites selected in our study, which could be the reason for its wide usage in most recent studies (Chen et al., 2000, Garrity et al., 2011 and Zhang et al., 2011). 


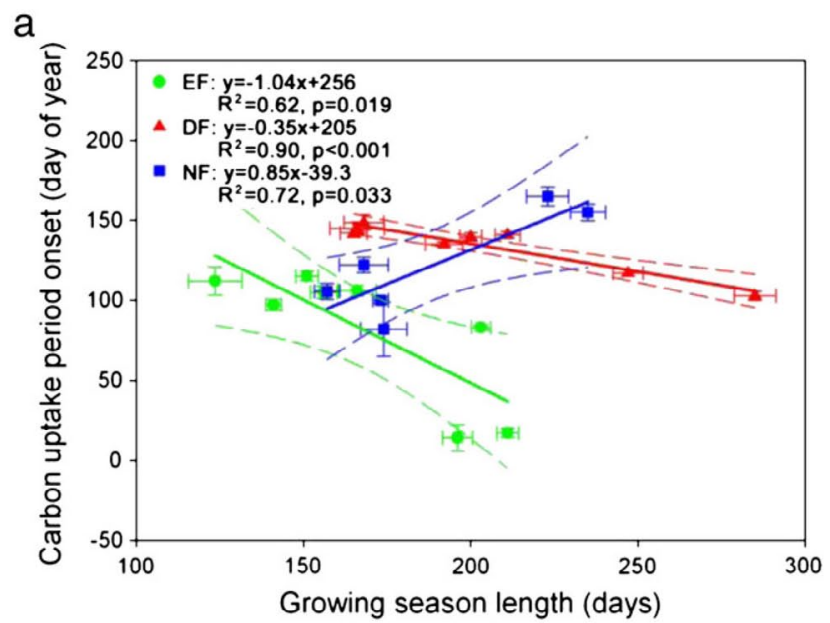

b

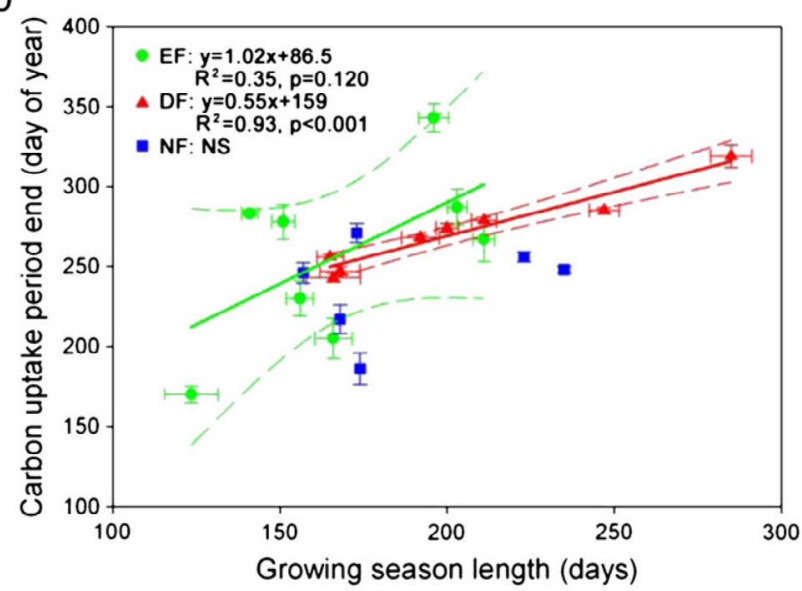

C

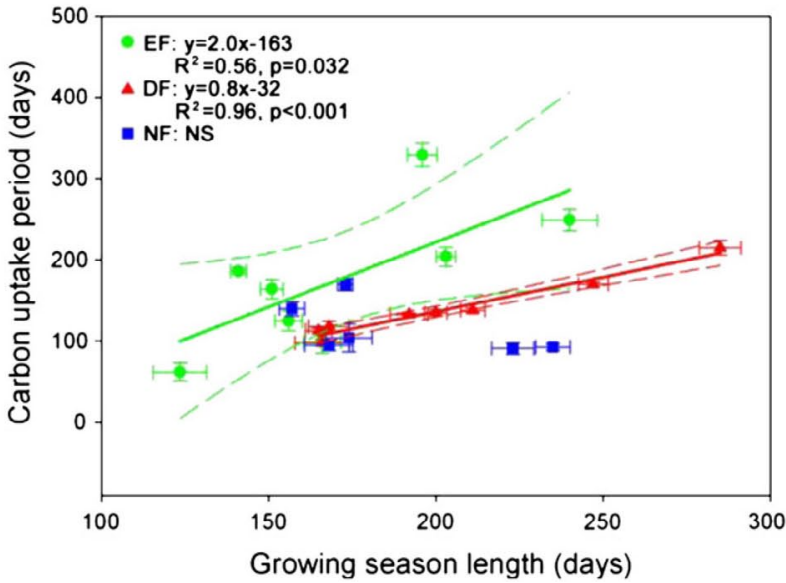

Fig. 9. Relationships between growing season length (GSL) (a) carbon uptake period onset (b) carbon uptake period end and (c) carbon uptake period for evergreen forest (EF), deciduous forest (DF), and non-forest sites. NS represents no significant correlation. Points represent data ( \pm standard error) for each site.

\subsubsection{Spatial relationships between CUP and spring and} autumn temperatures

We also analyzed the responses of CUP and its transitions to both spring and autumn temperatures and several correlations were shown in Table 2. Forest ecosystems had more strong correlations between the CUP and its transitions with both spring and autumn temperatures. For NF sites, we observed positive relationships between CUP onset and spring temperature $\left(\mathrm{R}^{2}=0.66, \mathrm{p}=0.046\right)$. However, the respective relationship for autumn temperature was not statistically significant $\left(\mathrm{R}^{2}\right.$ $=0.63, \mathrm{p}=0.057)$. Furthermore, no correlation had been acquired for either CUP or its ending date, indicating that seasonal temperature was not a major determinant of carbon uptake period and its transition in autumn for NF sites. The reason probably is that spring temperature generally triggers leaf-out and thus starting of CUP. On the other hand, CUP end of NF sites fluctuated between DOY 186 and 248 while autumn temperature was calculated as the mean value from Sep. to Nov, and this gap led to the low correlations observed. The forest (both EF and DF), showed strong and consistent correlations between the CUP and its transitions and the spring and autumn temperatures. Generally, higher spring and autumn temperatures would lead to an earlier onset of CUP, a later start of CUP ending date and longer CUP, all of which would enhance annual NEP. However, the EF sites tend to be more sensitive to such changes with almost three times larger in the slopes (statistically significant, $\mathrm{p}<0.05$ ), indicating higher spatial sensitivity of EF ecosystems than that of the DF sites.

\subsubsection{Spatial sensitivity of GSL to spring temperature}

Because the GSL here only depends on temperature, it is useful to understand its spatial pattern across regions and PFTs. We therefore calculated the slope of the correlation between GSL and spring temperature for all sites individually. The spatial pattern of this slope is shown in Fig. 10, which indicates a decreasing trend in this sensitivity with an increase in latitude $\left(\mathrm{R}^{2}=0.53, \mathrm{p}<0.001\right)$.

The sensitivity of GSL to spring temperature suggests that GSL in middle latitude regions tends to be more responsive to warmer spring temperature. GSL at the US-WBW site, which is located at $\sim 36^{\circ} \mathrm{N}$, shows the highest sensitivity to spring temperature with a value of 14 days per ${ }^{\circ} \mathrm{C}$. At latitudes near $54^{\circ} \mathrm{N}$ (e.g., SK-OA, SK-OBS and SKOJP), the slope has been reduced to 5.3 days per ${ }^{\circ} \mathrm{C}$ increase in spring temperature. This is consistent with previous result of Chen et al. (2000), in which a slope of 5.13 days per ${ }^{\circ} \mathrm{C}$ increase in the spring temperature was reported for three forest sites with an average latitude of $54.3^{\circ} \mathrm{N}$. This reduced sensitivity is an important finding as it provides a basis for understanding of latitudinal patterns of carbon uptake changes in response to future climate change. Warmer spring temperature will increase GSL in temperate regions more than in boreal regions and thus strengthens the existing latitudinal patterns of magnitudes in carbon fluxes, such as GPP. Therefore, ecosystem models should take this feature into consideration when predicting future carbon changes globally.

\subsubsection{Spatial sensitivities of NEP to spring temperature and GSL}

Falge et al., 2002a and Falge et al., 2002b previously analyzed the latitudinal sensitivity of NEP and GPP. In this study, we focused on the comparative responses of annual C fluxes to GSL and spring temperature

Table 2. Relationships between carbon uptake period and its transitions and spring and autumn temperatures.

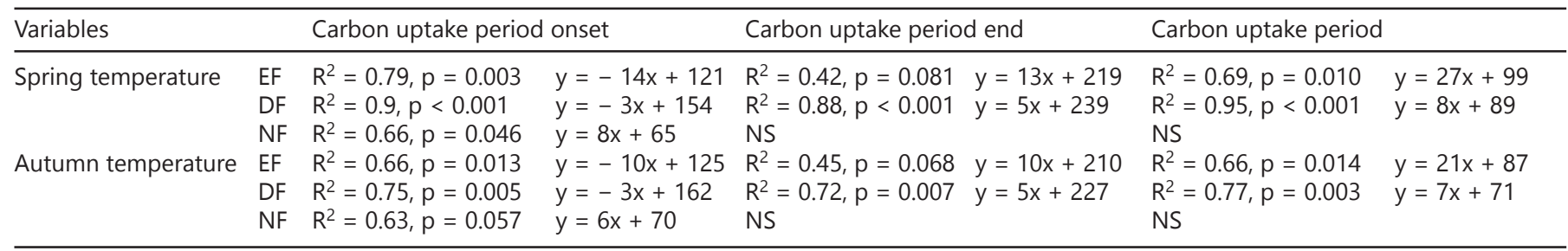




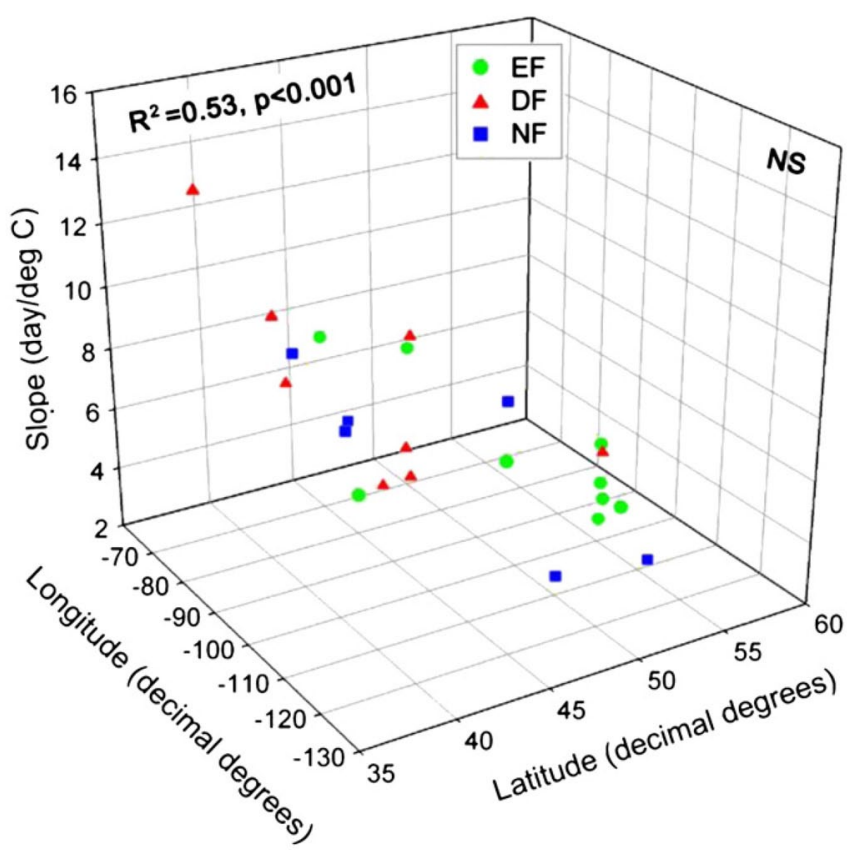

Fig. 10. Spatial analysis on the sensitivity of the growing season length to spring temperature. EF, DF and NF represent evergreen forests, deciduous forests, and non-forest sites, respectively. The overall regression is $y=-0.35 x+22.8\left(R^{2}=0.53, p<0.001\right)$.

with all site-year data for different PFTs and these correlations were all statistical significant $(\mathrm{p}<0.001)$ (Fig. 11). Different PFTs show large variations in their sensitivities to both spring temperature and GSL. GPP in EF sites exhibits the highest sensitivity to both spring temperature and GSL with GPP increasing by $220 \mathrm{~g} \mathrm{C} \mathrm{m}^{-2} \mathrm{y}^{-1}$ for each additional $1^{\circ} \mathrm{C}$ in spring temperature and $19 \mathrm{~g} \mathrm{C} \mathrm{m}^{-2} \mathrm{y}^{-1}$ for each additional day of GSL. In contrast, these values are largely reduced in DF and NF sites, with values of $\sim 55 \mathrm{~g} \mathrm{C} \mathrm{m}^{-2} \mathrm{y}^{-1}$ per ${ }^{\circ} \mathrm{C}$ and $\sim 6 \mathrm{~g} \mathrm{C} \mathrm{m}^{-2} \mathrm{y}^{-1} \mathrm{~d}^{-1}$, respectively. With respect to NEP, no such substantial variations are observed among PFTs. An increase of $1{ }^{\circ} \mathrm{C}$ in spring temperature increases annual NEP of 73, 42 and $22 \mathrm{~g} \mathrm{C} \mathrm{m}^{-2} \mathrm{y}^{-1}$ for EF, DF and NF sites, respectively. For each one day increase in GSL, NEP will increase by 5.7, 4.3 and $2.6 \mathrm{~g}$ $\mathrm{C} \mathrm{m}^{-2} \mathrm{y}^{-1}$ for EF, DF and NF sites, respectively.

\section{Discussion}

\subsection{Comparison between interannual and spatial responses}

The responses of annual NEP to phenological indicators were analyzed both interannually and spatially. However, we have revealed several features between these two parts.

The first aspect is the different degrees of such relationships. Spatial patterns of annual NEP to these phenological indicators were much stronger and evident than the interannual variations, which can be identified from the higher correlation coefficients and larger slopes. The more evident spatial responses we acquired agree with previous results of Richardson et al. (2010) that the slopes for spatial patterns were as twice as much of the interannual patterns. The much stronger of these correlations, by comparison, are much difficult to explain. We suggest some reasons that would explain such temporal and spatial differences. The ability of an ecosystem to sequent carbon from the atmosphere throughout a year may depend on many conditions, including its canopy structures, compositions, soil, age and the meteorological factors (e.g., temperature, precipitation, etc.). When the interannual patterns were analyzed with a site from year to year, the change in NEP would be mainly caused by the meteorological factors and the differences of
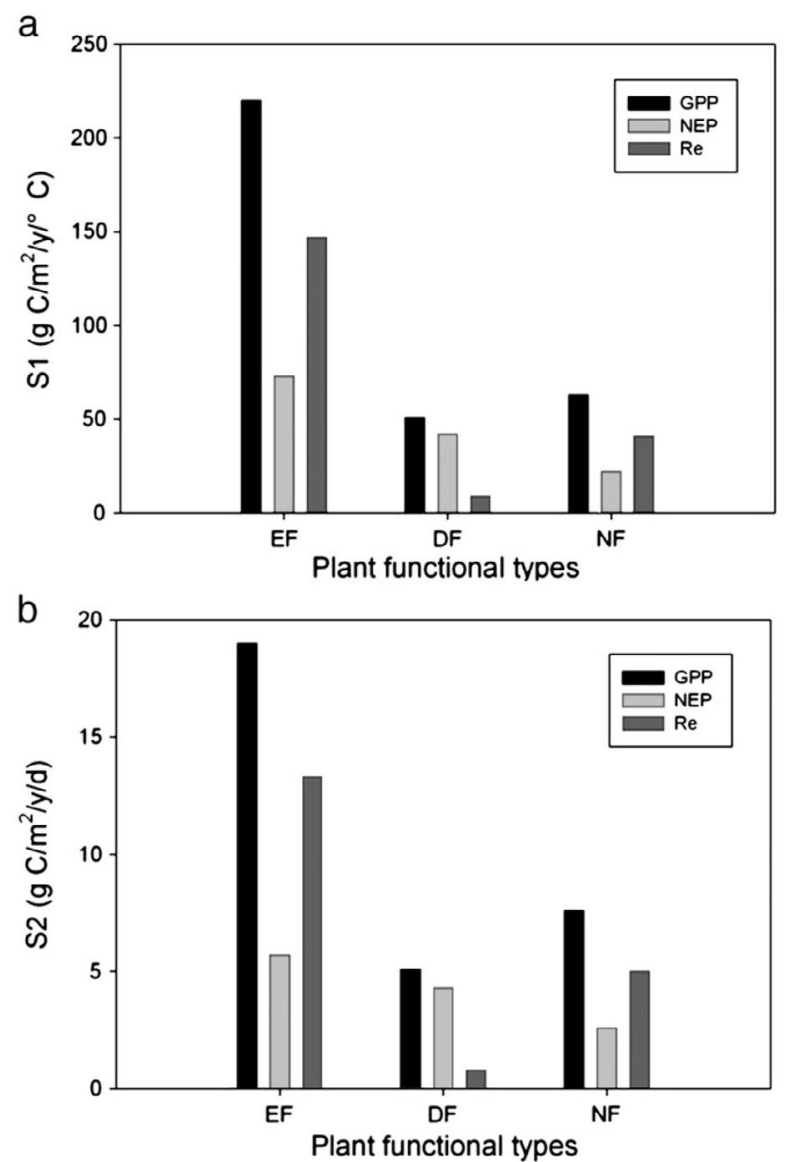

Fig. 11. Sensitivity of ecosystem carbon fluxes (GPP, NEP and Re) to (a) spring temperature and (b) growing season length. $\mathrm{S} 1$ (g C/m²/y/deg C) is the slope of the correlation between $\mathrm{C}$ fluxes and spring temperature and $\mathrm{S} 2\left(\mathrm{~g} \mathrm{C} / \mathrm{m}^{2} / \mathrm{y} /\right.$ day) is the slope of the correlation between $\mathrm{C}$ fluxes and GSL. EF, DF and NF represent evergreen forests, deciduous forests, and non-forest sites, respectively.

structures and compositions were excluded. By comparison, when the spatial patterns were considered, the changes associated with meteorological factors would be wiped out by averaging multi-year observations, leaving site specific differences of structures, soil prosperities and plant functional types. Therefore, we would expect larger differences between NEP of two sites than the differences of NEP for a site in different years. This larger range of NEP would first give larger slopes of the relationships between NEP and phenological indicators. Second, this larger dynamical range also implies that the NEP between sites would be more sensitive to phenological indicators and thus enhancing the correlations.

The second aspect is the general consistent sensitivity among PFTs when comparing the interannual and spatial responses. Interannually, evergreen forests were more adaptive to phenological variations as evidenced by the lower slopes. This feature existed in the spatial variations of annual NEP to these indicators except for the relationships between annual NEP and GSL where EF and DF had a similar range of slope (5.7 and 4.3 for EF and DF). These results may suggest that EF ecosystems would have a lower sensitivity of temporal-spatial variations of annual NEP in response to future climate change. The reason is that EF ecosystems may be potentially more adaptive to interannual variability in GSL with their relatively lower rates of photosynthesis continuing for longer periods and thus lower daily carbon fluxes (Baldocchi, 2008).

The third feature is the different trends of annual NEP to phenological changes interannually and spatially. For example, interannual variations in the onset of CUP would have negative impacts on annual NEP for the NF sites while its counterpart of spatial pattern was 
positive. Longer CUP would enhance annual NEP for NE sites interannually while it did not have evident impacts on annual NEP spatially. The most distinct feature lies in the spring and autumn temperatures. While both strong positive relationships were observed between annual NEP and spring and autumn temperatures spatially for all PFTs (Fig. 8), their interannual impacts on annual NEP showed substantial differences. No significant effects were acquired between annual NEP and the spring temperature for either PFTs. The negative impacts of autumn temperature on annual NEP in DF sites were expected, knowing as the effect of autumn warming (Piao et al., 2008). However, the EF and NF sites did not show such patterns, indicating that more variables (e.g., precipitation, soil moisture) would be helpful to better characterize interannual variability of NEP to autumn temperature.

\subsection{Roles of plant functional types on phenological analysis}

Spring temperature has been reported to have positive effects on the interannual annual NEP and the higher autumn temperature would, on the contrary, reduce interannual NEP (Black et al., 2000, Chen et al., 2003 and Piao et al., 2008). However, our results of multiple sites evaluation indicate that such responses would differ across sites and regions. Such diverse responses of interannual NEP to seasonal temperature were also observed in Richardson et al. (2010). One reason for these observations is that the temperature would have more evident impacts on carbon sequestration for those temperature controlled regions (e.g., boreal ecosystems). For our analysis with sites across large regions including both boreal and temperate ecosystems, such impact from the temperature would be mitigated. These diverse responses should be considered in the analysis of interannual carbon sequestration globally.

Since most of the previous research has focused on forest ecosystems (e.g., Richardson et al., 2010 and Zhang et al., 2011), our results indicate that the shifts in phenology of NF ecosystems may play a different role from forest ecosystems and could contribute to the spatial difference in large-scale NEP interpretation (Wang et al., 2011). For example, our results confirmed that CUP is an appropriate indicator of spatial patterns of annual NEP for forest ecosystems consistent with previous results of White and Nemani (2003) and Baldocchi (2008). However, its potential use in non-forest ecosystems is doubtful as indicated by our results (Fig. 6). The underlying mechanism of this correlation is not well understood at present, but should be explored in future analysis. For example, summer drought and soil water status can greatly reduce the net carbon uptakes for grasslands and crops $\mathrm{Mu}-$ galavai et al., 2008, Zha et al., 2010, Brümmer et al., 2011, Flanagan and Adkinson, 2011 and Wang et al., 2011). The low correlation is also reasonable considering results from previous research that the degrees of deleterious effects of environmental stresses (e.g., drought) may differ across PFTs (Granier et al., 2007).

One of the most interesting results among FPTs is that for the DF sites, the response of NEP is mostly attributed to the GPP response, despite GPP of DF sites having small slopes compared to EF sites. More than $80 \%$ of increased GPP due to warmer spring temperature or prolonged GSL is retained by the ecosystems in annual NEP. This high efficiency in accumulating carbon is consistent with previous study of Barr et al. (2007), which reports that GSL can enhance both GPP and NEP, yet shows no apparent effect on $\mathrm{R}_{\mathrm{e}}$ in a boreal deciduous forest. These results also agree with Richardson et al. (2009), who showed that NEP generally responded more to earlier springs for US-HA1 (DF) than for US-HO1 (EF). More importantly, our analysis indicates that DF ecosystems in other ecoregions may also exhibit this feature and suggests that future climate warming will favor deciduous species over evergreen species. We suggest that this finding further supports the previous suggestion that ecosystems with the greatest net carbon uptake have the longest growing season rather than the largest photosynthesis (Baldocchi, 2008).

\section{Conclusion}

We present an analysis of CUP, GSL, and spring and autumn temperatures on carbon sequestration in North America using 187-site-year data from 24 flux sites representing 10 evergreen forests (EF), 8 deciduous forests (DF), and 6 non-forests ecosystems (NF). The main limitation of our analysis is that by limiting to several flux sites, results from this study may be applicable for mesic sites in temperate and boreal regions in the continental US and Canada. This is of especial importance due the method used to calculate GSL, which is likely not be appropriate for other sites across North America where temperature may unlikely drop below the threshold (i.e., $5{ }^{\circ} \mathrm{C}$ ). This could be further addressed by exploring a different threshold that is allowed to vary for different ecosystems and latitudinal gradients. Nevertheless, our results showed that the responses of annual NEP to variations of phenological indicators would differ substantially across time and space, which should be carefully considered when modeling these impacts interannually and regionally. Several major points are concluded from our study:

(1) Interannual variability of annual NEP to phenological indicators tends to be less pronounced than that of the spatial variations, indicating an urgent need of assessing the appropriate strategies to modeling these effects. For example, while single spring or autumn temperature was unable to track interannual variability of NEP, the combined use of both may provide a solution.

(2) CUP and its transitions were correlated with annual NEP both temporally and spatially in forests while cares should be given in its use for NF sites. Spatially, a delayed CUP onset had a negative impact on annual NEP in forest ecosystems (both EF and DF), probably due to a delayed carbon sequestration time. However, there seems to be an unexpected positive impact on NF sites, suggesting the need for more analysis across PFTs.

(3) In general, the degree-day derived GSL was found to be a good indicator of annual NEP both across time and space, though the relationship was weaker at NF sites than at EF and DF sites. Both spring and autumn temperatures showed distinct patterns between interannually and spatially, probably due to other environmental stresses such as summer drought and water availability in NF ecosystems. We suggest that these variations across time and space could be one of the reasons for the heterogeneous spatial patterns of carbon sequestration under climate change (Wang et al., 2011).

(4) A decrease in the slope of the spatial relationship between GSL and spring temperature was observed with increasing latitude. As impacts of GSL on GPP and NEP are positive (Richardson et al., 2010), our results suggest that existing latitudinal gradient in these two carbon fluxes could be strengthened with future increase in spring temperature.

(5) Spatially, increase in spring temperature and GSL showed largest effects on GPP at EF sites, followed by NF and DF sites, respectively. However, owing to the highest contribution of $R_{e}$ in $E F$ sites, the impacts of GSL on NEP for these three PFTs did not exhibit large variations. Interestingly, most $(>80 \%)$ of the increased GPP due to warmer spring temperature and prolonged GSL in DF was retained in the annual NEP, which suggest a reconsideration of the ecological functions of DF species in the context of future climate change.

Acknowledgments - This work used flux sites from both the AmeriFlux and Fluxnet-Canada. We appreciate the PIs of these sites in providing the flux data and helpful explanations. This work was funded by an NSERC Strategic Grant (381474-09), the National Natural Science Foundation of China (Grant No. 41001210), and the Knowledge Innovation Program of the Chinese Academy of Sciences (KZCX2-EW-QN302). 


\section{References}

Admiral, S.W., Lafleur, P.M., 2007. Modelling of latent heat partitioning at a bog peatland. Agricultural and Forest Meteorology 144, 213-229.

Baldocchi, D.D., 2008. Breathing of the terrestrial biosphere: lessons learned from a global network of carbon dioxide flux measurement systems. Australian Journal of Botany 56, 1-26.

Barr, A.G., Black, T.A., Hogg, E.H., Kljun, N., Morgenstern, K., Nesic, Z., 2004. Interannual variability in the leaf area index of a boreal aspen-hazelnut forest in relation to net ecosystem production. Agricultural and Forest Meteorology 126, 237-255.

Barr, A.G., Black, T.A., Hogg, E.H., Griffis, T.J., Morgenstern, K., Kljun, N., Theede, A., Nesic, Z., 2007. Climatic controls on the carbon and water balances of a boreal aspen forest, 1994-2003. Global Change Biology 13, 561-576.

Beer, C., Reichstein, M., Tomelleri, E., Ciais, P., Jung, M., Carvalhais, N., Rödenbeck, C., Arain, M.A., Baldocchi, D., Bonan, G.B., Bondeau, A., Cescatti, A., Lasslop, G., Lindroth, A., Lomas, M., Luyssaert, S., Margolis, H., Oleson, K.W., Roupsard, O., Veenendaal, E., Viovy, N.,Williams, C., Ian Woodward, F., Papale, D., 2010. Terrestrial gross carbon dioxide uptake: Global distribution and covariation with climate. Science 329, 834-838.

Bernacchi, C.J., Hollinger, S.E., Meyers, T., 2005. The conversion of the corn/ soybean ecosystem to no-till agriculture may result in a carbon sink. Global Change Biology 11, 1867-1872.

Black, T.A., Chen, W.J., Barr, A.G., Arain, M.A., Chen, Z., Nesic, Z., Hogg, E.H., Neumann, H.H., Yang, P.C., 2000. Increased carbon sequestration by a boreal deciduous forest in years with a warm spring. Geophysical Research Letters 27, 1271-1274.

Brümmer, C., Black, T.A., Jassal, R.S., Grant, N.J., Spittlehouse, D.L., Chen, B., Nesic, Z., Amiro, B.D., Arain, M.A., Barr, A.G., Bourque, C.P.A., Coursolle, C., Dunn, A.L., Flanagan, L.B., Humphreys, E.R., Lafleur, P.M., Margolis, H.A., McCaughey, J.H., Wofsy, S.C., 2011. How climate and vegetation type influence evapotranspiration and water use efficiency in Canadian forest, peatland and grassland ecosystems. Agricultural and Forest Meteorology. http://dx.doi.org/10.1016/j.agrformet.2011.04.008.

Chen, J.M., Chen, W., Liu, J., Cihlar, J., 2000. Annual carbon balance of Canada's forests during 1895-1996. Global Biogeochemical Cycle 14, 839-850.

Chen, J.M., Ju, W., Cihlar, J., Price, D., Liu, J., Chen, W., Pan, J., Black, T.A., Barr, A., 2003. Spatial distribution of carbon sources and sinks in Canada's forests based on remote sensing. Tellus B 55, 622-642.

Churkina, G., Schimel, D., Braswell, B., Xiao, X., 2005. Spatial analysis of growing season length control over net ecosystem exchange. Global Change Biology 11, 1777-1787.

Cook, B.D., Davis, K.J., Wang, W., Desai, A., Berger, B.W., Teclaw, R.M., Martin, J.G., Bolstad, P.V., Bakwin, P.S., Yi, C., Heilman, W., 2004. Carbon exchange and venting anomalies in an upland deciduous forest in northern Wisconsin, USA. Agricultural and Forest Meteorology 126, 271-295.

Coursolle, C., Margolis, H.A., Barr, A.G., Black, T.A., Amiro, B.D., McCaughey, J.H., Flanagan, L.B., Lafleur, P.M., Roulet, N.T., Bourque, C.P.A., Arain, M.A., Wofsy, S.C., Dunn, A., Morgenstern, K., Orchansky, A.L., Bernier, P.Y., Chen, J.M., Kidston, J., Saigusa, N., Hedstrom, N., 2006. Late-summer carbon fluxes from Canadian forests and peatlands along an east-west continental transect. Canadian Journal of Forest Research 36, 783-800.

Curtis, P.S., Hanson, P.J., Bolstad, P., Barford, C., Randolph, J.C., Schmid, H.P., Wilson, K.B., 2002. Biometric and eddy-covariance based estimates of annual carbon storage in five eastern North American deciduous forests. Agricultural and Forest Meteorology 113, 3-19.

Denning, A.S., Nicholls, M., Prihodko, L., Baker, I., Vidale, P.L., Davis, K., Bakwin, P., 2003. Simulated variations in atmospheric CO2 over a Wisconsin forest using a coupled ecosystem-atmosphere model. Global Change Biology $9,1241-1250$.

Desai, A.R., Richardson, A.D., Moffat, A.M., Kattge, J., Hollinger, D.Y., Barr, A., Falge, E., Noormets, A., Papale, D., Reichstein, M., Stauch, V.J., 2008. Cross site evaluation of eddy covariance GPP and RE decomposition techniques. Agricultural and Forest Meteorology 148, 821-838.

Dragoni, D., Schmid, H.P., Grimmond, C.S.B., Loescher, H.W., 2007. Uncertainty of annual net ecosystem productivity estimated using eddy covariance flux measurements. Journal of Geophysical Research 112, D17102. http://dx.doi. org/10.1029/2006JD008149

Dragoni, D., Schmid, H.P., Wayson, C.A., Potters, H., Grimmond, C.S.B., Randolph, J.C., 2011. Evidence of increased net ecosystem productivity associated with a longer vegetated season in a deciduous forest in south-central Indiana, USA. Global Change Biology 17, 886-897.
Euskirchen, E.S., McGuire, A.D., Kicklighter, D.W., David, W., Zhuang, Q., Clein, J.S., Dargaville, R.J., Dye, D.G., Kimball, J.S., McDonald, K.C., Melillo, J.M., Romanovsky, V.E., Smith, N.V., 2006. Importance of recent shifts in soil thermal dynamics on growing season length, productivity, and carbon sequestration in terrestrial high-latitude ecosystems. Global Change Biology $12,731-750$.

Falge, E., Baldocchi, D., Tenhunen, J., Aubinet, M., Bakwin, P., Berbigier, P., Bernhofer, C., Burba, G., Clement, R., Davis, K.J., Elbers, J.A., Goldstein, A.H., Grelle, A., Granier, A., Gumundsson, J., Hollinger, D., Kowalski, A.S., Katul, G., Law, B.E., Malhi, Y., Meyers, T., Monson, R.K., Munger, J.W., Oechel, W., Paw, U.K.T., Pilegaard, K., Rannik, U., Rebmann, C., Suyker, A., Valentini, R., Wilson, K., Wofsy, S., 2002a. Seasonality of ecosystem respiration and gross primary production as derived from FLUXNET measurements. Agricultural and Forest Meteorology 113, 53-74.

Falge, E., Tenhunen, J., Baldocchi, D., Aubinet, M., Bakwin, P., Berbigier, P., Bernhofer, C., Bonnefond, J., Burba, G., Clement, R., 2002b. Phase and amplitude of ecosystem carbon release and uptake potentials as derived from FLUXNET measurements. Agricultural and Forest Meteorology 113, 75-95.

Fang, J., Piao, S., Field, C.B., Pan, Y., Guo, Q., Zhou, L., Peng, C., Tao, S., 2003. Increasing net primary production in China from 1982 to 1999 . Frontiers in Ecology and the Environment 1, 293-297.

Flanagan, L.B., Adkinson, A.C., 2011. Interacting controls on productivity in a northern Great Plains grassland and implications for response to ENSO events. Global Change Biology. http://dx.doi.org/10.1111/j.1365-2486.2011.02461.x

Flanagan, L.B., Syed, K.H., 2011. Stimulation of both photosynthesis and respiration in response to warmer and drier conditions in a boreal peatland ecosystem. Global Change Biology 17, 2271-2287.

Garrity, S.R., Maurer, K.D., Mueller, K.L., Vogel, C.S., Curtis, P.S., 2011. A comparison of multiple phenology data sources for estimating seasonal transitions in deciduous forest carbon exchange. Agricultural and Forest Meteorology. http://dx.doi.org/10.1016/j.agrformet.2011.07.008

Giasson, M.A., Coursolle, C., Margolis, H.A., 2006. Ecosystem-level CO2 fluxes from a boreal cutover in eastern Canada before and after scarification. Agricultural and Forest Meteorology 140, 23-40.

Granier, A., Reichstein, M., Breda, N., Janssens, I.A., Falge, E., Ciais, P., Grünwald, T., Aubinet, M., Berbigier, P., Bernhofer, C., Buchmann, N., Facini, O., Grassi, G., Heinesch, B., Ilvesniemi, H., Keronen, P., Knohl, A., Köstner, B., Lagergren, F., Lindroth, A., Longdoz, B., Loustau, D., Mateus, J., Montagnani, L., Nys, C., Moors, E.J., Papale, D., Peiffer, M., Pilegaard, K., Pita, G., Pumpanen, J., Rambal, S., Rebmann, C., Rodrigues, A., Seufert, G., Tenhunen, J., Vesala, T., Wang, Q., 2007. Evidence for soil water control on carbon and water dynamics in European forests during the extremely dry year: 2003. Agricultural and Forest Meteorology 143, 123-145.

Grant, R.F., Barr, A.G., Black, T.A., Margolis, H.A., Mccaughey, J.H., Trofymow, J.A., 2010. Net ecosystem productivity of temperate and boreal forests after clearcutting - a Fluxnet-Canada measurement and modelling synthesis. Tellus B 62, 475-496.

Hanson, P.J., Wullschleger, S.D., Norby, R.J., Tschaplinski, T.J., Gunderson, C.A., 2005. Importance of changing CO2, temperature, precipitation, and ozone on carbon and water cycles of an upland-oak forest: incorporating experimental results into model simulations. Global Change Biology 11, 1402-1423.

Hollinger, D.Y., Aber, J., Dail, B., Davidson, E.A., Goltz, S.M., Hughes, H., Leclerc, M.Y., Lee, J.T., Richardson, A.D., Rodrigues, C., Scott, N.A., Achuatavarier, D., Walsh, J., 2004. Spatial and temporal variability in forest-atmosphere CO2 exchange. Global Change Biology 10, 1689-1706.

Jassal, R.S., Black, T.A., Spittlehouse, D.L., Brümmer, C., Nesic, Z., 2009. Evapotranspiration and water use efficiency in different-aged Pacific Northwest Douglas-fir stands. Agricultural and Forest Meteorology 149, 1168-1178.

Kurz, W.A., Dymond, C.C., White, T.M., Stinson, G., Shaw, C.H., Rampley, G.J., Smyth, C., Simpson, B.N., Neilson, E.T., Trofymow, J.A., Metsaranta, J., Apps, M.J., 2009. CBMCFS3: a model of carbon-dynamics in forestry and land-use change implementing IPCC standards. Ecological Modelling 220, 480-504.

Law, B.E., Falge, E., Gu, L., Baldocchi, D.D., Bakwin, P., Berbigier, P., Davis, K., Dolman, A.J., Falk, M., Fuentes, J.D., Goldstein, A., Granier, A., Grelle, A., Hollinger, D., Janssens, I.A., Jarvis, P., Jensen, N.O., Katul, G., Mahli, Y., Matteucci, G., Meyers, T., Monson, R., Munger, W., Oechel, W., Olson, R., Pilegaard, K., Paw, U.K.T., Thorgeirsson, H., Valentini, R., Verma, S., Vesala, T., Wilson, K., Wofsy, S., 2002. Environmental controls over carbon dioxide and water vapor exchange of terrestrial vegetation. Agricultural and Forest Meteorology 113, 97-120.

Linderholm, H.W., 2006. Growing season changes in the last century. Agricultural and Forest Meteorology 137, 1-14. 
Liu, X., Yin, Z.Y., Shao, X., Qin, N., 2006. Temporal trends and variability of daily maximum and minimum, extreme temperature events, and growing season length over the eastern and central Tibetan Plateau during 1961-2003. Journal of Geophysical Research 111, D19109. http://dx.doi. org/10.1029/2005JD006915.

Melesse, A.M., Hanley, R.S., 2005. Artificial neural network application for multiecosystem carbon flux simulation. Ecological Modelling 189, 305-314.

Meyers, T.P., Luke, W.T., Meisinger, J.J., 2006. Fluxes of ammonia and sulfate over maize using relaxed eddy accumulation. Agricultural and Forest Meteorology 136, 203-213.

Moffat, A.M., Papale, D., Reichstein, M., Richardson, A.D., Barr, A.G., Beckstein, C., Braswell, B.H., Churkina, G., Desai, A.R., Falge, E., Gove, J.H., Heimann, M., Hui, D., Jarvis, A.J., Kattge, J., Noormets, A., Stauch, V.J., 2007. Comprehensive comparison of gap-filling techniques for eddy covariance net carbon fluxes. Agricultural and Forest Meteorology 147, 209-232.

Monson, R.K., Sparks, J.P., Rosenstiel, T.N., Scott-Denton, L.E., Huxman, T.E., Harley, P.C., Turnipseed, A.A., Burns, S.P., Backlund, B., Hu, J., 2005. Climatic influences on net ecosystem $\mathrm{CO} 2$ exchange during the transition from wintertime carbon source to springtime carbon sink in a high-elevation, subalpine forest. Oecologia 146, 130-147.

Morisette, J.T., Richardson, A.D., Knapp, A.K., Fisher, J.I., Graham, E.A., Abatzoglou, J., Wilson, B.E., Breshears, D.D., Henebry, G.M., Hanes, J.M., Liang, L., 2009. Tracking the rhythm of the seasons in the face of global change: phenological research in the 21 st Century. Frontiers in Ecology and the Environment 7, 253-260.

Mugalavai, E.M., Kipkorir, E.C., Raes, D., Rao, M.S., 2008. Analysis of rainfall onset, cessation and length of growing season for western Kenya. Agricultural and Forest Meteorology 148, 1123-1135.

Pan, Y., Birdsey, R.A., Fang, J., Houghton, R., Kauppi, P.E., Kurz, W.A., Phillips, O.L., Shvidenko, A., Lewis, S.L., Canadell, J.G., Ciais, P., Jackson, R.B., Pacala, S., McGuire, A.D., Piao, S., Rautiainen, A., Sitch, S., Hayes, D., 2011. A large and persistent carbon sink in the world's forests. Science. http://dx.doi. org/10.1126/science. 1201609

Papale, D., Valentini, A., 2003. A new assessment of European forests carbon exchange by eddy fluxes and artificial neural network spatialization. Global Change Biology 9, 525-535.

Papale, D., Reichstein, M., Aubinet, M., Canfora, E., Bernhofer, C., Kutsch, W., Longdoz, B., Rambal, S., Valentini, R., Vesala, T., Yakir, D., 2006. Towards a standardized processing of net ecosystem exchange measured with eddy covariance technique: algorithms and uncertainty estimation. Biogeosciences $3,571-583$.

Piao, S., Ciais, P., Friedlingstein, P., Peylin, P., Reichstein, M., Luyssaert, S., Margolis, H., Fang, J., Barr, A., Chen, A., Grelle, A., Hollinger, D.Y., Laurila, T., Lindroth, A., Richardson, A.D., Vesala, T., 2008. Net carbon dioxide losses of northern ecosystems in response to autumn warming. Nature 451, 49-52.

Reichstein, M., Falge, E., Baldocchi, D., Papale, D., Aubinet, M., Berbigier, P., Bernhofer, C., Buchmann, N., Gilmanov, T., Granier, A., Grunwald, T., Havrankova, K., Ilvesniemi, H., Janous, D., Knohl, A., Laurila, T., Lohila, A., Loustau, D., Matteucci, G., Meyers, T., Miglietta, F., Ourcival, J.M., Pumpanen, J., Rambal, S., Rotenberg, E., Sanz, M., Tenhunen, J., Seufert, G., Vaccari, F., Vesala, T., Yakir, D., Valentini, R., 2005. On the separation of net ecosystem exchange into assimilation and ecosystem respiration: review and improved algorithm. Global Change Biology 11, 1424-1439.

Richardson, A.D., Hollinger, D.Y., Dail, D.B., Lee, J.T., Munger, J.W., O’Keefe, J., 2009. Influence of spring phenology on seasonal and annual carbon balance in two contrasting New England forests. Tree Physiology 29, 321-331.

Richardson, A.D., Black, T.A., Ciais, P., Delbart, N., Friedl, M.A., Gobron, N., Hollinger, D.Y., Kutsch, W.L., Longdoz, B., Luyssaert, S., Migliavacca, M., Montagnani, L., Munger, J.W., Moors, E., Piao, S., Rebmann, C., Reichstein, M., Saigusa, N., Tomelleri, E., Vargas, R., Varlagin, A., 2010. Influence of spring and autumn phenological transitions on forest ecosystem productivity. Philosophical Transactions of the Royal Society B-Biological Sciences $365,3227-3246$.

Teklemariam, T., Staebler, R.M., Barr, A.G., 2009. Eight years of carbon dioxide exchange above a mixed forest at Borden, Ontario. Agricultural and Forest Meteorology 149, 2040-2053.
Thomas, C.K., Law, B.E., Irvine, J., Martin, J.G., Pettijohn, J.C., Davis, K.J., 2009. Seasonal hydrology explains interannual and seasonal variation in carbon and water exchange in a semiarid mature ponderosa pine forest in central Oregon. Journal of Geophysical Research 114, G04006. http://dx.doi. org/10.1029/2009JG001010

Urbanski, S., Barford, C., Wofsy, S., Kucharik, C., Pyle, E., Budney, J., McKain, K., Fitzjarrald, D., Czikowsky, M., Munger, J.W., 2007. Factors controlling $\mathrm{CO}_{2}$ exchange on timescales from hourly to decadal at Harvard Forest. Journal of Geophysical Research 112, G02020. http://dx.doi. org/10.1029/2006JG000293

Valentini, R., Matteucci, G., Dolman, A.J., Schulze, E.D., Rebmann, C., Moors, E.J., Granier, A., Gross, P., Jensen, N.O., Pilegaard, K., Lindroth, A., Grelle, A., Bernhofer, C., Grünwald, T., Aubinet, M., Ceulemans, R., Kowalski, A.S., Vesala, T., Rannik, U., Berbigier, P., Loustau, D., Gudmundsson, J., Thorgeirsson, H., Ibrom, A., Morgenstern, K., Clement, R., 2000. Respiration as the main determinant of carbon balance in European forests. Nature 404, $861-865$.

Verma, S., Dobermann, A., Cassman, K., Walters, D.T., Knops, J.M., Arkebauer, T.J., Suyker, A.E., Burba, G.G., Amos, B., Yang, H., Ginting, D., Hubbard, K.G., Gitelson, A.A., Walter-Shea, A.E., 2005. Annual carbon dioxide exchange in irrigated and rainfed maize-based agroecosystems. Agricultural and Forest Meteorology 131, 77-96.

Vitasse, Y., François, C., Delpierre, N., Dufrêne, E., Kremer, A., Chuine, I., Delzon, S., 2011. Assessing the effects of climate change on the phenology of European temperate trees. Agricultural and Forest Meteorology 151, 969-980.

Wang, X.H., Piao, S.L., Ciais, P., Li, J.S., Fredlingstein, P., Koven, C., Chen, A.P., 2011. Spring temperature change and its implication in the change of vegetation growth in North America from1982 to 2006. Proceedings of the National Academy of Sciences 108, 1240-1245.

White, M.A., Nemani, R.R., 2003. Canopy duration has little influence on annual carbon storage in the deciduous broad leaf forest. Global Change Biology $9,967-972$.

White, M.A., Running, S.W., Thornton, P.E., 1998. The impact of growing-season length variability on carbon assimilation and evapotranspiration over 88 years in the eastern US deciduous forest. International Journal of Biometeorology 42, 139-145.

Wilson, K.B., Baldocchi, D.D., 2000. Seasonal and interannual variability of energy fluxes over a broadleaved temperate deciduous forest in North America. Agricultural and Forest Meteorology 100, 1-18.

Wu, C., Chen, J.M., Gonsamo, A., Price, D.T., Black, T.A., Kurz, W.A., 2012. Interannual variability of carbon sequestration is determined by the lag between ends of net uptake and photosynthesis: evidence from long records at two contrasting forest stands. Agricultural and Forest Meteorology. 164, 29-38.

Yuan, W.P., Luo, Y.Q., Richardson, A.D., Oren, R., Luyssaert, S., Janssens, I.A., Ceulemans, R., Zhou, X.H., Grunwald, T., Aubinet, M., Berhofer, C., Baldocchi, D.D., Chen, J.Q., Dunn, A.L., Deforest, J.L., Dragoni, D., Goldstein, A.H., Moors, E.J., Munger, J.W., Monson, R.K., Suyker, A.E., Star, G., Scott, R.L., Tenhunen, J., Verma, S.B., Vesala, T., Wofsy, S., 2009. Latitudinal patterns of magnitude and interannual variability in net ecosystem exchange regulated by biological and environmental variables. Global Change Biology 15, 2905-2920.

Zha, T., Barr, A.G., van der Kamp, G., Black, T.A., McCaughey, J.H., Flanagan, L.B., 2010. Interannual variation of evapotranspiration from forest and grassland ecosystems in western Canada in relation to drought. Agricultural and Forest Meteorology 150, 1476-1484.

Zhang, W.J., Wang, H.M., Yang, F.T., Yi, Y.H., Wen, X.F., Sun, X.M., Yu, G.R., Wang, Y.D., Ning, J.C., 2011. Underestimated effects of low temperature during early growing season on carbon sequestration of a subtropical coniferous plantation. Biogeosciences 8, 1667-1678.

Zhu, W., Tian, H., Xu, X., Pan, Y., Chen, G., Lin, W., 2011. Extension of the growing season due to delayed autumn over mid and high latitudes in North America during 1982-2006. Global Ecology and Biogeography. http://dx.doi. org/10.1111/j.1466-8238.2011.00675.x 